\title{
Getting to the bottom of bycatch: a GIS-based toolbox to assess the risk of marine mammal bycatch
}

\author{
Ellen Hines ${ }^{1, *}$, Louisa S. Ponnampalam ${ }^{2}$, Chalatip Junchompoo ${ }^{3}$, Cindy Peter ${ }^{4}$, \\ Long $\mathrm{Vu}^{5}$, Thien Huynh ${ }^{6,7}$, Marjolaine Caillat ${ }^{8}$, Andrew F. Johnson ${ }^{9,10}$, Gianna Minton ${ }^{11}$, \\ Rebecca L. Lewison ${ }^{12}$, Gregory M. Verutes ${ }^{13,14}$ \\ ${ }^{1}$ Estuary \& Ocean Science Center, and Department of Geography \& Environment, San Francisco State University, Tiburon, \\ CA 94920, USA \\ ${ }^{2}$ The MareCet Research Organization, 47630 Subang Jaya, Selangor, Malaysia \\ ${ }^{3}$ Department of Marine and Coastal Resources, Ministry of Natural Resources and Environment, Chaeng Watthana Road, \\ Lak Si District, Bangkok 10210, Thailand \\ ${ }^{4}$ Universiti Malaysia Sarawak, Jalan Datuk Mohammad Musa, 94300 Kota Samarahan, Sarawak, Malaysia \\ ${ }^{5}$ Vietnam Marine Megafauna Network, Center for Biodiversity Conservation and Endangered Species, 24, Street No 13, \\ Lakeview City, Ho Chi Minh City, Vietnam \\ ${ }^{6}$ Southern Institute of Ecology, Vietnam Academy of Science and Technology, 01 Mac Dinh Chi, Ben Nghe, District 1, Ho Chi Minh City, \\ Vietnam \\ ${ }^{7}$ Graduate School of Natural Science and Technology, Kanazawa University, Kakumamachi, Kanazawa, Ishikawa 920-1164, Japan \\ ${ }^{8}$ Environmental Defense Fund, San Francisco, CA 94105, USA \\ ${ }^{9}$ MarFishEco Fisheries Consultants, 67/6 Brunswick Street, Edinburgh EH7 5HT, UK \\ ${ }^{10}$ The Lyell Centre, Institute of Life and Earth Sciences, School of Energy, Geoscience, Infrastructure and Society, \\ Heriot-Watt University, Edinburgh, EH14 4AS, UK \\ ${ }^{11}$ Megaptera Marine Conservation, 2242 PT Wassenaar, The Netherlands \\ ${ }^{12}$ Department of Biology, San Diego State University, CA 92182, USA \\ ${ }^{13}$ Faculty of Political and Social Sciences, Universidade de Santiago de Compostela, Praza do Obradoiro, 0 , \\ 15705 Santiago de Compostela, A Coruña, Spain \\ ${ }^{14}$ Campus Do*Mar, International Campus of Excellence, 36310 Vigo, Spain
}

\begin{abstract}
Marine mammal bycatch poses a particular challenge in developing countries, where data to document bycatch and its effects are often lacking. Using the Bycatch Risk Assessment (ByRA) toolkit, based on InVEST open-source models, we chose 4 field sites in Southeast Asia with varying amounts of data on marine mammals and fishing occurrence: Trat province in the eastern Gulf of Thailand, the Sibu-Tinggi Islands and Kuching Bay, Malaysia, and Kien Giang Biosphere Reserve in southwestern Vietnam. These field sites have similar species of coastal marine mammals, small-scale and commercial fisheries, and support for research from universities and/or management. In Thailand and Kuching, results showed changing patterns of fishing and Irrawaddy dolphin Orcaella brevirostris habitat use across seasons, showing how bycatch risk could change throughout the year. Risk maps for dugongs Dugong dugon in peninsular Malaysia highlighted patterns of bycatch risk concentrated around a mainland fishing pier, and revealed high risk in a northern subregion. In Vietnam, first maps of bycatch risk for the Irrawaddy dolphin showed the highest risk driven by intensive use of gillnets and trawling gear. ByRA pinpointed areas of spatial and seasonal bycatch exposure, and estimated the consequence of bycatch on local species, providing managers with critical information on where to focus bycatch mitigation and meet new global standards for US Marine Mammal Protection Act and other international regulation (e.g. Official Journal of the European Union 2019; Regulation 2019/1241) compliance. The toolbox, a transferable open-source tool, can be used to guide fisheries management, marine mammal conservation, spatial planning, and further research.
\end{abstract}

KEY WORDS: Incidental bycatch · Marine mammals · Spatial risk assessment · Open-source GIS toolkit $\cdot$ Small-scale fisheries $\cdot$ Southeast Asia

${ }^{*}$ Corresponding author: ehines@sfsu.edu

() The authors 2020. Open Access under Creative Commons by Attribution Licence. Use, distribution and reproduction are unrestricted. Authors and original publication must be credited. 


\section{INTRODUCTION}

Fisheries bycatch, the unintended capture of nontarget species, has been recognized as the most serious threat to marine mammals for decades (Reeves et al. 2013). A rough estimate of marine mammal bycatch suggests an estimated 300000 cetaceans are taken each year by fisheries globally (Read et al. 2006). In many countries, fisheries bycatch of marine mammal species is poorly monitored or regulated, so impacts of bycatch on local populations are not well understood. Even in countries where marine mammal abundance and distribution estimates are available, gaps in data on fishing effort and gear use, bycatch rates, and the fate of animals post-capture are key obstacles that impede the ability to characterize or quantify the risk of fisheries bycatch on resident marine mammal populations (Goldsworthy \& Page 2007, Soykan et al. 2008, Hines et al. 2012, 2015a, Teh et al. 2015). Due to a lack of resources that impedes local scientific capacity, data limitations are often greatest in developing countries, where marine fisheries can comprise a significant contribution to local and even national economies (Briscoe et al. 2014).

The 2017 International Affairs and Seafood Inspection rule from the NOAA Office of International Affairs in the United States stipulates that seafood imports to the United States need to comply with Marine Mammal Protection Act (MMPA) regulations that require the monitoring and reduction of marine mammal bycatch (Federal Register 2016). Countries with relevant fisheries exporting to the United States have 5 yr from January 2017 to document their compliance. In many of these countries there are significant data gaps on marine mammal distribution and abundance and bycatch rates, especially in developing countries (Williams et al. 2016, Johnson et al. 2017). The MMPA rule and similar regulations from the European Union (e.g. European Union Council Regulation 2019/1241; Official Journal of the European Union 2019) have intensified the need for better data to monitor and report marine mammal bycatch and fisheries-related population impacts.

Helping governments that rely on fisheries exports to address these gaps has been one of the drivers for the creation of the Bycatch Risk Assessment (ByRA) toolbox. This toolbox allows the spatial/temporal assessment of bycatch risk using any amount of data, identifying areas for critical research and possibly immediate management actions while accounting for reliability and robustness in toolbox results. The need for more data to inform conservation manage- ment and policy can also delay conservation action. There is an equally strong need to make better use of existing data to develop bycatch risk assessments for marine mammals of conservation concern, and use these data to improve population-level estimates and inform management strategies (Stelzenmüller et al. 2015). Risk assessments identify, analyze, and evaluate the likelihood or probability of an event happening, and the consequences of that event (Gibbs \& Browman 2015).

Spatial risk assessments in a geographic information systems (GIS) environment are valuable tools that incorporate diverse data quality to evaluate areas where management can be most effective (Grech et al. 2008). While high-precision and highresolution data yield assessments with low levels of uncertainty (as long as uncertainty is accurately described and accounted for), even low-resolution information can be used to characterize bycatch risk and prioritize sites, gear types, and seasons for monitoring, and to guide future data collection efforts (Hoffman \& Hammonds 1994, Briscoe et al. 2014).

Reducing bycatch to sustainable levels for marine mammal populations will require collaborative efforts among scientists, conservation organizations, resource managers, industry, and local communities. This integration must include an economic perspective and account for the behavior and decision-making of fishers (Lewison et al. 2004, Teh et al. 2015). The nature of small-scale fisheries frequently makes traditional means for monitoring and quantifying bycatch nearly impossible: vessels are often too small to host on-board fisheries observers; fishing areas are too remote and dispersed to allow effective monitoring of landing sites; and resources are often lacking to implement remote electronic monitoring or other means to document bycatch. At the same time, a high proportion of these fisheries are using gillnets in nearshore areas, a combination known to be the main driver for decreases in endangered populations of small cetaceans around the globe (Brownell et al. 2019). As such, in order to plan effective mitigation measures, even in the absence of direct observations of bycatch, tools are desperately needed to allow the estimation of bycatch risk in areas where fisheries and coastal marine mammals overlap. Bycatch situations and therefore solutions are local and placebased, controlled by diverse biophysical, cultural, economic, and political criteria. However, commonalities in many of these issues allow the application of this framework to guide the creation and analysis of a spatially explicit bycatch risk analysis locally and globally. 
The idea for ByRA came from several approaches that spatially modeled the impact of human activities on the abundance and distribution of different taxa. Samhouri \& Levin (2012) and Arkema et al. (2014) estimated risk scenarios using the dimensions of consequence and exposure and created an open-source habitat risk assessment (HRA) model (Sharp et al. 2018) that was incorporated into the InVEST toolbox for the Natural Capital Project (https://naturalcapitalproject.stanford.edu/). Specifically for marine mammals, Briscoe et al. (2014) modeled the risk of fisheries bycatch for an area of limited data for dugongs Dugong dugon along the coast of Sabah, Malaysia. The resulting risk surface map incorporated existing data and identified areas of high risk for areas where dugong surveys had and had not been conducted.

Modeled after the HRA and the Briscoe et al. (2014) methods, our toolkit visually presents spatial and temporal bycatch risk information, making it easier for scientists and managers to identify and predict areas of likely persistent bycatch and test management scenarios to reduce bycatch (Lewison et al. 2009, Briscoe et al. 2014).

Here, we tested the newly developed ByRA toolbox to create a spatially explicit geodatabase for 4 fishing sites across 3 countries. This process used existing data to characterize the distribution and abundance of marine mammal species of conservation concern, fisheries occurrence and interaction rates, and other anthropogenic factors that characterize bycatch risk. These efforts pointed to the need for a transferable open-source tool that supports spatial decisionmaking/planning to reduce and prevent marine mammal bycatch, and provided a means for developing countries to comply with recent international regulations on fisheries exports to the US market.

\section{MATERIALS AND METHODS}

\subsection{Study sites}

Dunn et al. (2010) and Stewart et al. (2010) undertook a comprehensive, multi-year study to quantify the spatial extent of fishing effort and density in several coastal regions of the world's oceans. One of these regions, Southeast Asia, is a region of high species biodiversity coupled with high fishing density (Roberts et al. 2002, Stewart et al. 2010). The International Union for Conservation of Nature (IUCN) Species Survival Commission's Cetacean Specialist Group's 2002-2010 Conservation Action Plan recom- mends research initiatives to identify special areas of 'cetacean abundance for special conservation attention' in Southeast Asia, as well as to document cetacean bycatch in these areas (Reeves et al. 2003, p. 60).

We chose our study sites - Trat province on the eastern Gulf coast of Thailand, Sibu-Tinggi Islands and Kuching Bay, Malaysia, and the Kien Giang Biosphere Reserve in southwestern Vietnam - based on established collaborations with local scientists and varying amounts of pre-existing data with which to test our toolbox model (Fig. 1). In all 3 countries, we had the support of local management agencies and researchers. Furthermore, Thailand and Vietnam are also the largest Southeast Asian exporters of commercial fish to the United States (with a value of USD 156261104 and 116776983 in fish products in 2018, respectively) (NOAA Office of Science and Technology Commercial Fisheries Statistics). The study sites are described in the order of overall data availability, from Thailand, which has the most research on animals and fisheries, to Vietnam, where little research has been done.

\subsubsection{Trat Province, Thailand}

Trat Province is located along the eastern coast of the Gulf of Thailand and is an important fishing area for local communities (Fig. 1). Trat is also habitat for Irrawaddy dolphins Orcaella brevirostris, Indo-Pacific finless porpoises Neophocaena phocaenoides, and Indo-Pacific humpback dolphins Sousa chinensis. Studies of local cetacean populations have largely been conducted by boat and aerial surveys, and have demonstrated that the most abundant local cetacean species is the Irrawaddy dolphin (Hines et al. 2015b). Aerial and ship-based line transect and photo-identification surveys have been conducted since 2003, and are ongoing (e.g. Junchompoo et al. 2013). Five years of line transect surveys yielded an average relative abundance estimate of 423 (95\% CI = 252-734) Irrawaddy dolphins (Hines et al. 2015b).

The most common fishing gears used by the local small-scale fishery communities in Trat Bay are gillnets and crab traps (54\% and $25 \%$, respectively), although a total of 14 types of fishing gear are used in the area. The high density of fishing gear is likely the major threat to dolphins in this area (Junchompoo et al. 2013).

The Department of Marine and Coastal Resources is the main agency responsible for Thailand's marine resources. Research on marine mammals and their conservation is conducted in collaboration with many 

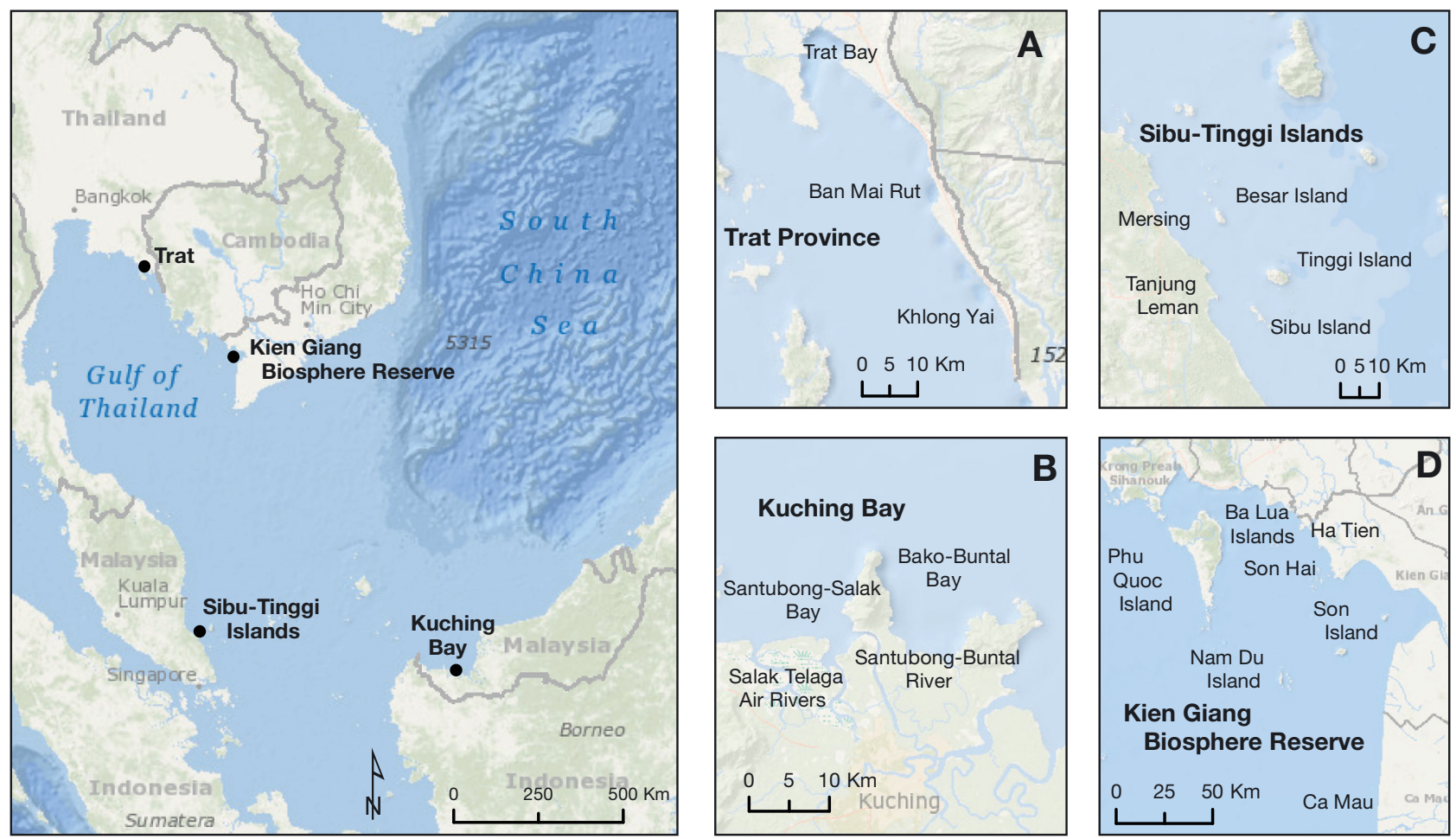

Fig. 1. Locations of the 4 study sites: (A) Trat Province, Thailand, (B) Kuching Bay, Sarawak, East Malaysia, (C) Sibu-Tinggi Islands, Johor Province, Malaysia, and (D) the Kien Giang Biosphere Reserve, Vietnam

additional agencies including the Department of Fisheries, the Department of National Parks Wildlife and Plant Conservation, the Royal Thai Navy, and local NGOs.

\subsubsection{Kuching Bay, Sarawak, Malaysia}

Kuching Bay is located approximately $50 \mathrm{~km}$ from Kuching, Sarawak, in East Malaysia, and includes Salak-Santubong Bay, Bako-Buntal Bay, and several interconnecting rivers (Fig. 1). The 2 major estuaries/ bays are shallow, with depths not exceeding $10 \mathrm{~m}$ as far as $15 \mathrm{~km}$ offshore. The study site within Kuching Bay includes several terrestrial and marine protected areas, protected under Sarawak's National Parks and Nature Reserves Ordinance (Chapter 27, 1998, http:// lawnet.sarawak.gov.my/lawnet_file/Ordinance/ORD_ CAP. \%2027\%20watermark.pdf). All species of cetaceans are protected under the Wild Life Protection Ordinance (Chapter 26, 1998, https://www.sarawak forestry.com/pdf/laws/wildlife_protection_ordinance 98_chap26.pdf) and anyone who kills, hunts, sells, or captures cetaceans may be subjected to fines and/or imprisonment. The agency responsible for enforcing this ordinance is the Sarawak Forestry Corporation.
In 2008, the Sarawak Dolphin Project was initiated and housed under Universiti Malaysia Sarawak (UNIMAS) with the aim of collecting baseline data on the distribution and habitat use of coastal dolphins in Sarawak. Over subsequent years, the UNIMAS team has conducted monthly boat-based surveys of Irrawaddy dolphins, finless porpoises, and Indo-Pacific humpback dolphins, as well as observations of their interactions with local fisheries. Photo identification studies by Minton et al. $(2011,2013)$ yielded estimates of 233 Irrawaddy dolphins $(95 \%$ CI $=151-$ 360 ), while line transect analyses resulted in an estimate of 149 Irrawaddy dolphins (95\% CI $=87-255)$ in the bay (Minton et al. 2013).

Approximately 1150 fishers operate in the Kuching Bay area, for both local consumption and commercial sale (Annual Fisheries Statistics 2018). Fisheries activities were recorded during boat-based surveys between March 2011 and August 2013, and were complemented by interviews with fishers from 5 coastal villages surrounding Kuching Bay. Both interviews and direct observations revealed that gillnets are the most commonly used gear, with a clear post-monsoon (March-May) seasonal peak in the presence of attended gillnets, when fishers stayed at a net, and a peak in unattended gillnets, when fishers left a net 
between setting it and pulling it in, in the pre-monsoon season from September to December. Peter et al. (2016) recorded the relative density of observed fishing activity, which indicated a strong overlap between the primary fishing areas and the preferred habitats of Irrawaddy dolphins, which are concentrated in rivers, river mouths, and close to the shore.

\subsubsection{Sibu-Tinggi Islands, Johor, Malaysia}

The Seribuat Archipelago is a group of tropical islands located in the South China Sea, 4-6 nautical miles, $\mathrm{n}$ miles) off the east coast of Johor state in Peninsular Malaysia (Fig. 1). These islands, particularly the Sibu group and Tinggi (SBTG), are core habitats for a small population of dugongs Dugong dugon, the last remaining area in Peninsular Malaysia where the species is reliably found (Ponnampalam et al. 2015). The seagrass meadows, especially at Besar, Sibu, and Tinggi, have been identified as important feeding grounds for dugongs as well as sea turtles (Ponnampalam et al. 2015).

The islands in the Seribuat Archipelago have been Federal Marine Parks since 1994, and are managed by the Division of Marine Parks and Resource Management of the Department of Fisheries Malaysia, a federal government agency. Each island's marine park boundary stretches $2 \mathrm{n}$ miles from the lowest water mark and constitutes a complete no-take zone; collectively, the island marine parks are branded as the Sultan Iskandar Marine Park. In 2016, the Johor state government proposed and declared its commitment for a Johor Dugong Sanctuary to be established, the status of which, as of this writing, is still pending official gazette from the federal government. Dugongs are considered an endangered species in Malaysia, and are protected in Peninsular Malaysia under the Fisheries Act 1985. However, seagrass meadows have no specific legal protection unless they fall within marine park waters, an inconsistency that may prove important to the future of Malaysia's dugong populations.

Research since 2010 has revealed that Sibu Island is the main feeding and nursery ground of dugongs in the wider area, while Tinggi Island is a feeding ground and vocal hotspot for dugong communications (Ponnampalam et al. 2015). Results of aerial surveys estimated that the population is small, with daily maximum counts not exceeding 20 animals sighted. Nearly $24 \%$ of sightings were of mother-calf pairs, indicating a reproducing population (L. S. Ponnampalam unpubl. data).
The human populations of the islands are composed of local villagers, resort workers, and tour operators who run snorkeling, SCUBA diving, and angling trips. While the waters out to $2 \mathrm{n}$ miles from the islands are a no-take zone, there are still local villagers who work as artisanal fishers and fish for subsistence close to shore. The main types of fishing gear used by artisanal fishers in this site are 3-layered monofilament trammel nets, driftnets, rods, and cage traps locally known as bubu. Fisheries regulations in Malaysia state that commercial trawlers are to operate at least $5 \mathrm{n}$ miles from shore. However, aerial surveys in 2010 and 2014-2016 yielded observations of encroachment in waters less than $5 \mathrm{n}$ miles from the coast and within the no-take zones of the marine park (L. S. Ponnampalam unpubl. data). In total, there were 1607 local and 3129 foreign fishers registered in the local area in 2018 (Department of Fisheries, Malaysia 2018).

Since 2015, there have been at least 18 recorded cases of dugong deaths from around Sibu and Tinggi Islands, all of which were juveniles. Some had evidence of death resulting from interactions with human activities. At least 2 of those dugongs had died from being caught in an illegal longline deployed in the area and known locally as rawai hantu (ghost longline). One longline alone is fitted with 10000 fishing hooks (L. S. Ponnampalam unpubl. data).

\subsubsection{Kien Giang Biosphere Reserve}

The Southwest Gulf of Vietnam is in the eastern Gulf of Thailand. Extending from the Cambodia border to Ca Mau Cape, the total coastline is $312 \mathrm{~km}$ (Fig. 1). The UNESCO Kien Giang Biosphere Reserve (KGBR) was designated in 2006. Phú Quốc Island is the largest of 105 islands in the reserve. As a transition zone between the Gulf of Thailand and South China Sea, this area is recognized by the Vietnamese government as an important fishing zone. Reports on provincial fisheries can be found in the Kien Giang Department of Fisheries, which only accounts for registered boats. According to those reports, in 2014, there were 10880 registered fishing boats in Kien Giang province and total catch was 636170 tons, or $20 \%$ of the total seafood landings in Vietnam.

To date, research on marine mammals in Vietnam, including the KGBR, has not been conducted regularly, nor with enough coverage spatially to assess which species are present or the status of any population. Vu (2014) conducted boat surveys for cetaceans in 2014-2015 along the northeast coast of the 
Reserve and around Phú Quốc Island to the west (Fig. 1), resulting in 4 sightings of 19 Irrawaddy dolphins, and 2 of finless porpoises. The non-profit Vietnam Marine Megafauna Network has been actively involved in marine mammal conservation in KGBR since 2014 (Vu 2014). The other local NGO, Wildlife at Risk, has regularly conducted educational programs concerning dugong conservation around Phú Quốc Island in western KGBR since 2010.

When bycatch takes place inside the boundary of KGBR (Fig. 1), it immediately falls under the scope of the KGBR Management Board. KGBR's marine mammals, which are categorized as aquatic resources by Vietnamese law, are also under the management of the Kien Giang Department of Natural Resources and Environment. Marine mammal bycatch, directly related to fisheries, is the responsibility of the Fishery Agency of the Kien Giang Department of Agriculture and Rural Development.

\subsection{ByRA overview}

ByRA assesses the risk of bycatch based on the spatial and temporal coincidence of ranked probabilities of overlap between a species occurrence and fishing. Based on the Habitat Risk Assessment (HRA) tool created for the Natural Capital Project InVEST toolbox (Sharp et al. 2018), risk to species caused by a stressor is calculated as the weighted average of exposure, or the degree to which a species experiences stress due to a human activity (spatial/temporal overlap, intensity, status of management strategies), and consequence, the species-specific resilience and sensitivity to a stressor (mortality, life stages affected, etc.) (Samhouri \& Levin 2012, Arkema et al. 2014). Exposure is the overlap between a species' distribution and the extent of a human activity in space and time. Consequence, in terms of sensitivity, is an expert assessment of how a population will respond to an impact. In terms of resilience, consequence is based on a scientific assessment of the population dynamics and life history of a species (Arkema et al.
2014). The collaborators for each site populated exposure and consequence tables with ratings that scored each stressor (see Table S1 in the Supplement at www.int-res.com/articles/suppl/n042p037_supp. pdf). Bycatch risk was then calculated as the straight line (Euclidean) distance of the summed exposure and consequence scores (Sharp et al. 2018). If a stressor was not applicable in a specific area, a score of zero (0) omitted that stressor from further assessment. The ByRA output was a series of GIS layers, showing these risk scores for each site or region, and a map layer for the species classified by the relative amount of risk (high/medium/low).

Beyond the HRA, we developed 3 new spatially explicit criteria specifically for the ByRA tool (Table 1). The first, which assessed the current status of management actions, was based on marine and fisheries management information to indicate where management strategies have been identified or implemented. Intensity was based on fishing gear-type density, and was computed by the model. The intensity of fishing activity by gear type often varied across space and could be mapped as a surface using spatial interpolation tools available in a GIS. Likelihood of interaction between fisheries and species was also calculated by the toolbox as the sum of habitat suitability (see below) ranking (1-3) and a combined fishing occurrence and gear-type intensity rating (1-3), then reclassified from lowest to highest (1-3). The rationale was that if both a species and gear had a high probability of being present in a given area, the likelihood of interaction or bycatch was also high.

\subsection{Data compilation}

We collected data on the physical and biological environment, as well as animal sightings from surveys and interviews from each field site. ByRA was specifically formatted to include the most commonly used data formats. We also reviewed the literature to access the most relevant, recent local data. Table 2 shows a preliminary assessment of existing local data

Table 1. Specialized exposure criteria for the Bycatch Risk Assessment (ByRA) toolkit

\begin{tabular}{|lcccc|}
\hline Risk level & 3 & 2 & 1 & No score (0) \\
\hline Current status of & Management strategy & Management strategy & No strategy \\
management actions & identified and implemented & identified & Not known \\
Intensity & High intensity & Medium intensity & Low intensity & Not known \\
Likelihood of interaction & High likelihood & Medium & Low & Not known \\
\hline
\end{tabular}


Table 2. Preliminary assessment of existing data in each field site

\begin{tabular}{|c|c|c|c|c|}
\hline & Trat Province, Thailand & Kuching, Malaysia & $\begin{array}{l}\text { Sibu-Tinggi Islands, } \\
\text { Malaysia }\end{array}$ & Kien Giang, Vietnam \\
\hline ByRA species & $\begin{array}{l}\text { Irrawaddy dolphin } \\
\text { Orcaella brevirostris }\end{array}$ & $\begin{array}{l}\text { Irrawaddy dolphin } \\
\text { Orcaella brevirostris }\end{array}$ & $\begin{array}{l}\text { Dugong Dugong } \\
\text { dugon }\end{array}$ & $\begin{array}{l}\text { Irrawaddy dolphin } \\
\text { Orcaella brevirostris }\end{array}$ \\
\hline Environmental data & $\begin{array}{l}\text { Depth, distance to river } \\
\text { mouths, distance to } \\
\text { land/Also salinity, pH, } \\
\text { turbidity, chlorophyll a } \\
\text { \& temperature 2008, } \\
\text { 2009, 2012-2014 }\end{array}$ & $\begin{array}{l}\text { Depth, distance to river } \\
\text { mouths, distance to } \\
\text { land/also temperature, } \\
\text { pH, turbidity, tide level } \\
\text { \& salinity 2009-2012 }\end{array}$ & $\begin{array}{l}\text { Depth, distance to } \\
\text { river mouths, distance } \\
\text { to land }\end{array}$ & $\begin{array}{l}\text { Depth, distance to } \\
\text { river mouths, } \\
\text { distance to land/also } \\
\text { temperature } \\
(2014-2015) \text { and } \\
\text { salinity (2015) }\end{array}$ \\
\hline $\begin{array}{l}\text { Animal survey } \\
\text { transects and/or } \\
\text { photo-ID }\end{array}$ & $\begin{array}{l}\text { Boat surveys 2008, 2009, } \\
2012-2016\end{array}$ & Boat surveys 2008-2013 & $\begin{array}{l}\text { Aerial surveys } 2010 \text {, } \\
2014-2016 \text {; boat } \\
\text { surveys 2014-2016 }\end{array}$ & $\begin{array}{l}\text { Boat surveys } \\
2014-2015\end{array}$ \\
\hline Sightings & 1674 & 882 & 1360 & 4 \\
\hline Fishing occurrences & $\begin{array}{l}\text { Boat surveys 2008, 2009, } \\
\text { 2012-2016 }\end{array}$ & Boat surveys 2011-2013 & $\begin{array}{l}\text { Aerial surveys } 2010 \text {, } \\
2014-2016 \text {; boat } \\
\text { surveys 2014-2016 }\end{array}$ & $\begin{array}{l}\text { Boat surveys } \\
2014-2015\end{array}$ \\
\hline Fishing areas & Expert knowledge & Expert knowledge & $\begin{array}{l}\text { Community interviews } \\
2010,2015-2017\end{array}$ & $\begin{array}{l}\text { Community inter- } \\
\text { views and expert } \\
\text { knowledge 2014, } \\
2016\end{array}$ \\
\hline $\begin{array}{l}\text { Interviews \& } \\
\text { workshops }\end{array}$ & $2008,2009,2012-2015$ & 2010-2012 & $2010,2015-2017$ & 2014,2016 \\
\hline Protected areas & Proposed & $\begin{array}{l}\text { National Parks/ } \\
\text { RAMSAR site }\end{array}$ & Proposed & Biosphere Reserve \\
\hline Bycatch information & $\begin{array}{l}\text { Thai Department of } \\
\text { Marine and Coastal } \\
\text { Resource maps and } \\
\text { records/local stranding } \\
\text { network }\end{array}$ & No systematic reporting & $\begin{array}{l}\text { No systematic } \\
\text { reporting }\end{array}$ & $\begin{array}{l}\text { No systematic } \\
\text { reporting }\end{array}$ \\
\hline
\end{tabular}

readily available. Data on fishing effort by season, fishing areas, and the type of gear used were obtained from surveys, interviews or expert knowledge and incorporated into layers of fisheries risk. While information from the scientific literature is the most useful for objectivity and repeatability (Hobday et al. 2011, Arkema et al. 2014), expert opinion (Teck et al. 2010, Maxwell et al. 2013) and interview responses (Hines et al. 2005, Ortega-Argueta et al. 2012, Pilcher et al. 2017), even with potential biases and misinformation, are especially useful in data-poor situations. There is a precedent for interviews especially to be an efficient, low-cost method for gathering data to contribute to knowledge on relative abundance and fisheries risk that contribute to conservation and management planning (Hines et al. 2005, Pilcher et al. 2017).

For each site, we chose to focus on the more abundant species seen in surveys. For example, in Trat Province, Thailand, 7 yr of line transect boat survey data were available from 2008 to 2014 (dry season), and 2014 to 2016 (wet and dry seasons), with the Irrawaddy dolphin being the most numerous cetacean species observed (Junchompoo et al. 2013, Hines et al. 2015b, Jackson-Ricketts et al. 2020). In the SibuTinggi Island area, the distribution and habitat use of the local population of dugongs had been studied through aerial surveys during the dry season in 2010 (Ponnampalam et al. 2015) and from 2014 to 2016, along with research on foraging in extensive seagrass beds around the islands and the distribution of human activities (L. S. Ponnampalam unpubl. data). In Kuching Bay, Sarawak, both line transect and photo-identification methods were used to analyse data gathered from sightings in boat surveys from 2008 to 2013. These surveys were conducted regularly throughout the year, enabling us to analyze habitat use during the post-monsoon (March-May), dry (May-September), and pre-monsoon (September-December) seasons. Irrawaddy dolphins were the most frequently encountered cetaceans at this site (Minton et al. 2011, 2013, Peter et al. 2016). For the KGBR, during the Vu (2014) boat surveys, Irrawaddy dolphins were most commonly observed, but the numbers of all sightings were too low for abundance estimation. We listed the 
types of fishing gear that are primarily seen in bycatch incidents. These were divided into 5 common categories: nets (including purse seine and gillnets), trawlers, pots and traps, longlines, and hook and line. Specific gears in each of these categories are given for each site in Table 3. We determined the risk levels of each gear for each site for the consequence and exposure tables (see Table S1 in the Supplement). Nets were classified as representing the highest risk for bycatch, followed by trawlers, longlines, pots and traps, and, lastly, hook and line gear.

We gathered data on fishing occurrences, areas, gear use, and seasonality of fishing for each site (Table 2). Fishing occurrences, in this context, were defined for each site by the type and amount of data we were able to access. For most sites, fishing occurrences consisted of boat-based sightings, or aerial surveys, combined with interviews and/or expert knowledge of areas where boats usually go and during what season.

Bathymetric data for our field sites varied in quality and quantity. The ByRA tool is able to incorporate bathymetric depth of any format and resolution. We created maps of bathymetry in the Sibu-Tinggi Islands by georeferencing and digitizing a British Admiralty Chart, and incorporated nearshore depth points collected during ship surveys. For KGBR, we digitized bathymetric charts from 1963 analog charts from the US Naval Oceanographic Office. For Kuching and Trat, there were no bathymetric charts available with sufficient resolution. However, a depth sounder was used to collect data during both ceta- cean surveys. In GIS, we interpolated the depth data into bathymetric surfaces using an inverse distance weighted interpolation algorithm, which estimated values over a surface by averaging the values of the known points within a specified neighborhood of each sampled point (Philip \& Watson 1982).

We created between 2 and 8 subregions within each area based on conservation, geopolitical, and ecological factors (Fig. 2). For Trat, we used the 2region study areas defined by the Thai Department of Marine and Coastal Resources for surveys in the wet southwest monsoon season, between April and November, and the 3-region strata used for the dry season (November-March) boat-based surveys (2008 to 2016) (Hines et al. 2015b). We divided Kuching Bay and its expansive river system into the 4 strata described in Minton et al. (2013) and Peter et al. (2016). In the Sibu-Tinggi islands, our boundary contained potential management zones based on dugong distribution data in areas where the MareCet Research Organization had conducted their aerial monitoring surveys. We created 4 subregions based on management strategies (e.g. no-take, no trawling) being considered for the critical dugong habitats. In KGBR, we included areas of less than $20 \mathrm{~km}$ from the coast bounded by the management boundaries. We then divided this area into the 7 survey strata used by the Vietnam Marine Megafaunal Network (Vu 2014). We created an eighth zone within the northern extent of the KGBR to represent the area, partly in Vietnam, monitored by Marine Conservation Cambodia, an NGO based in nearby Cambodia.

Table 3. Common groupings of specific gears commonly seen in marine mammal bycatch for each field site

\begin{tabular}{|c|c|c|c|c|c|}
\hline & Nets & Trawlers & Pots \& traps & Longlines & Hook \& line \\
\hline Trat, Thailand & $\begin{array}{c}\text { Gillnet (crab, shrimp) } \\
\text { Purse seine } \\
\text { Surrounding }\end{array}$ & $\begin{array}{l}\text { Trawlers } \\
\text { Push net }\end{array}$ & $\begin{array}{l}\text { Crab trap } \\
\text { Octopus trap }\end{array}$ & Longline - hook & Single hook \\
\hline $\begin{array}{l}\text { Kuching Bay, } \\
\text { Malaysia }\end{array}$ & $\begin{array}{c}\text { Gillnet } \\
\text { Set net (nylon) } \\
\text { Drift net } \\
\text { Trammel net }\end{array}$ & Trawlers & Pots \& traps & $\begin{array}{l}\text { Longline - high } \\
\text { Longline - low }\end{array}$ & Rod line \\
\hline $\begin{array}{l}\text { Sibu-Tinggi Islands, } \\
\text { Malaysia }\end{array}$ & $\begin{array}{c}\text { Gillnet } \\
\text { Purse seine } \\
\text { Drift net }\end{array}$ & Trawlers & Traps & Longline - bottom & Hook \& line \\
\hline $\begin{array}{l}\text { Kien Giang, } \\
\text { Vietnam }\end{array}$ & $\begin{array}{l}\text { Anchovy purse seine } \\
\text { Mackerel purse seine } \\
\text { Purse seine with lights } \\
\text { Bottom gillnet } \\
\text { (shrimp/crab) } \\
\text { Surface gillnet (sardine) } \\
\text { Crab trammel net } \\
\text { Small mesh trammel net } \\
\text { Frame-attached set net }\end{array}$ & $\begin{array}{l}\text { Single trawl } \\
\text { Pair trawl } \\
\text { Electric trawl }\end{array}$ & $\begin{array}{l}\text { Crab trap } \\
\text { Cuttlefish trap } \\
\text { Octopus trap }\end{array}$ & $\begin{array}{c}\text { Fish hooks \& } \\
\text { lines }\end{array}$ & $\begin{array}{l}\text { Squid hook } \\
\text { and line }\end{array}$ \\
\hline
\end{tabular}



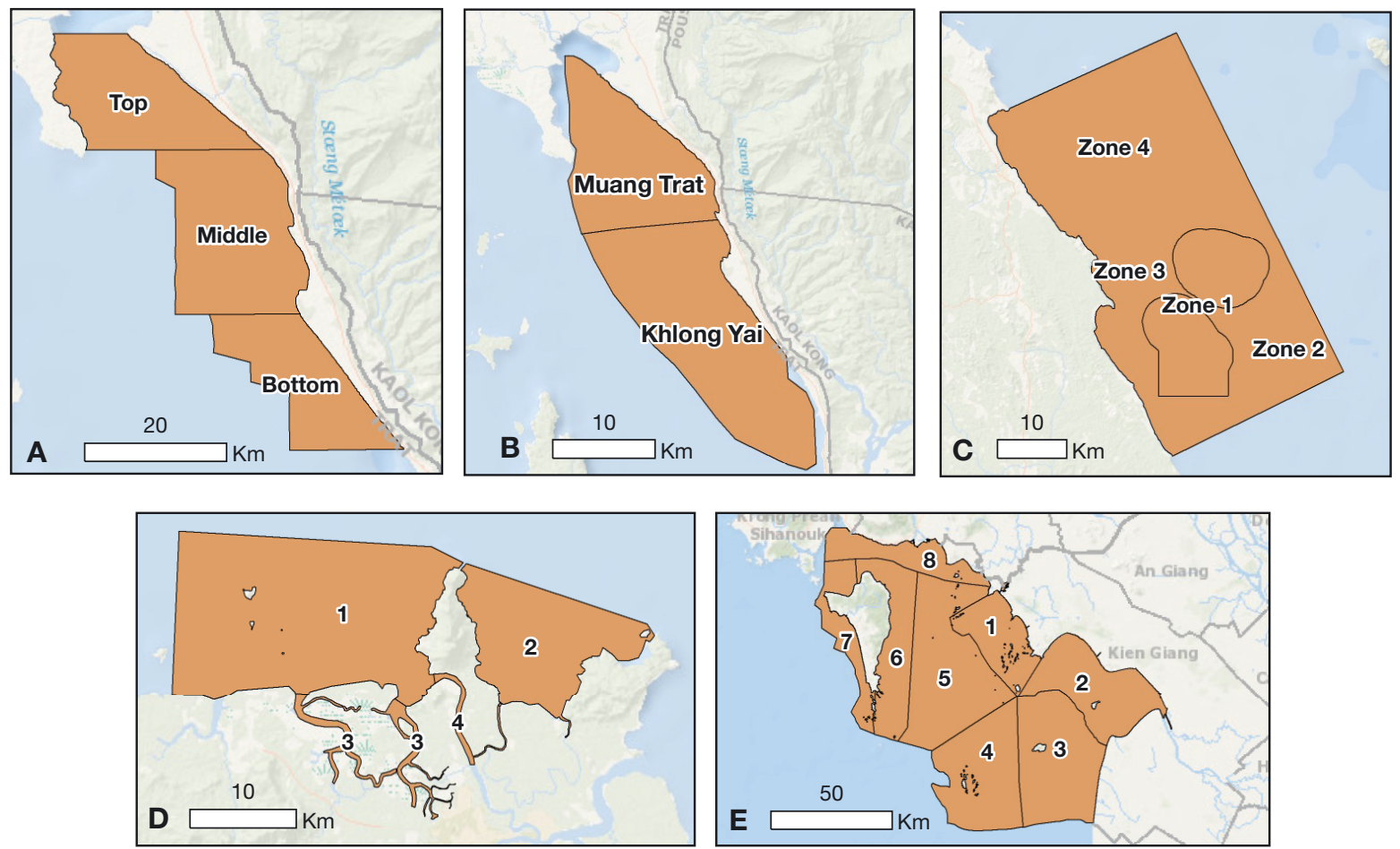

Fig. 2. Subregions for the 4 Southeast Asian field sites. (A) Three subregions for Trat in the dry season. (B) Northern and southern subregions for Trat in the wet season. (C) Four zones in the Sibu-Tinggi Island area. (D) Kuching Bay subregions: 1, SantubongSalak Bay; 2, Bako Buntal Bay; 3, Salak Telaga Air Rivers; and 4, Santubong Buntal River. (E) Zones 1-7 in the Kien Giang Biosphere Reserve, Vietnam. Zone 8 is along the Vietnam/Cambodia border

\subsection{Habitat modeling}

An important input layer for the ByRA incorporated the best available information on species distribution, from which we created habitat models for each species at each location. Habitat models are important tools for linking cetacean observations to ecological variables and identifying critical habitat (Redfern et al. 2006, Gregr et al. 2013). The models used to delineate habitat depended on the number of surveys and/or animals sighted. Depth, distance to land, slope, and distance to river mouths have been shown by numerous researchers to be commonly important measures of habitat suitability for dugongs and coastal cetaceans, including Irrawaddy dolphins (see Minton et al. 2011, Briscoe et al. 2014 [for dugongs], Peter et al. 2016, Jackson-Ricketts et al. 2020). When enough survey-based sightings were available, such as in Trat, Kuching Bay, and the Sibu-Tinggi Islands, we used the modeling software Maxent, which is suitable for small sample sizes (Pearson et al. 2007, Elith et al. 2011, Briscoe et al. 2014). Maxent is a presence-only data model that quantifies the statistical relationship between predictor environmental covariates at locations where a species has been observed, versus background locations in which no species have been observed within the studied region (Phillips et al. 2006). We used the $\mathrm{R}$ package ENMeval (Muscarella et al. 2014) to apply Maxent across a range of different locations in setting and balancing model fit and predictive ability (Muscarella et al. 2014, Rhoden et al. 2017). As the ByRA output was a representation of risk scores classified to 3 levels (high/medium/low), the Maxent suitable habitat outputs were also divided into 3 categories based on the probability of occurrence predicted by the best model for each cell of the map. Please see the 'Habitat modeling' section in the Supplement for more information.

In Vietnam, we had only 4 sightings of Irrawaddy dolphins. For sample sizes below 10, Maxent results are less robust (Pearson et al. 2007). Briscoe et al. (2014) first showed how a rule-based GIS approach could be used to designate areas of marine mammal habitat in an area with little data, in that case, dugongs along northern Sabah, Malaysia. We incorporated and improved on that method for the ByRA in the KGBR. Based on the environmental variables 
found relevant for Irrawaddy dolphins (see above), we used GIS to create spatial overlay maps of bathymetry, distance to land, and river mouths to depict levels of habitat use.

\subsection{Uncertainty standards}

Based on the data available, as well as the spatial and temporal extent, we used a stoplight approach to catagorize input and output uncertainty for each site. We first created a reference table of uncertainty standards from which we could judge the existing information available (Table 4). Data characterized as green, or those in which we had the most confidence, were based on robust and defensible research methodologies. For example, sightings data in this category were collected during formal transect or photo-identification surveys, and sufficient sightings were accumulated for the statistical analysis of relative abundance. Habitat distribution and suitability here could be quantified based on sightings, locations, and a systematic collection of environmental variables. Data on fishing gear and spatial occurrence, for a green classification, were collected formally as well, usually noted during abundance surveys, and optimally observing variations by season. For bycatch or stranding data, the highest standard included robust and sufficient data for an estimation of a local bycatch rate.

The yellow category contained data collected opportunistically, without formal surveys, with minimal or no environmental variables collected. Habitat use here was estimated only by overlaid environ- mental variables and based on sightings and criteria for the species in the literature. Estimates of fishing gear, occurrence, and bycatch here were based on community interviews or the opinion of local scientists, NGO, or agency personnel.

The red, or least certain, category included surveys with insufficent data for abundance analysis, or only opportunistic sightings by fishermen obtained by interview. Habitat use was based soley on estimated environmental variables from the literature. Fishing occurrence was estimated by expert opinion and interviews. There was little to no effort in this category to record incidences or species from bycatch or stranding incidences.

\section{RESULTS}

\subsection{Fishing occurrence}

The spatial distribution of fishing occurrence and gear is shown in Fig. 3. The top map (Fig. 3A) shows the distribution of gear in Trat, Thailand, based on sightings during boat surveys for Irrawaddy dolphins (Jackson-Ricketts 2016). In the wet season (Fig. 3, left), longline gear was prevalent, and seen close to shore and up into the shallow bay to the north. In the southern area of Trat province, longlines were seen offshore. In contrast, there was much more fishing during the dry season, with more gillnets seen throughout the region, and no longline gear noted.

In Kuching Bay, net distribution data were also gathered during boat surveys. Gillnets were the most commonly used gear in all 3 seasons. Gillnet occur-

Table 4. A reference table of uncertainty standards for Bycatch Risk Assessment (ByRA) criteria classification

\begin{tabular}{|l|l|l|l|}
\hline & \multicolumn{1}{|c|}{ Green } & \multicolumn{1}{c|}{ Yellow } & \multicolumn{1}{c|}{ Red } \\
\hline $\begin{array}{l}\text { Animal sightings } \\
\text { distribution }\end{array}$ & $\begin{array}{l}\text { Data collected during formal } \\
\text { transect or photo ID survey; } \\
\text { data can be used to estimate } \\
\text { relative abundance }\end{array}$ & $\begin{array}{l}\text { Sightings/photo ID collected } \\
\text { during opportunistic surveys }\end{array}$ & $\begin{array}{l}\text { Few sightings collected, no } \\
\text { abundance estimation } \\
\text { possible; sightings only } \\
\text { available from interviews }\end{array}$ \\
\hline Habitat suitability & $\begin{array}{l}\text { Estimated from modeling, } \\
\text { formal collection of environ- } \\
\text { mental variables }\end{array}$ & $\begin{array}{l}\text { Rule-based estimation, } \\
\text { minimal environmental } \\
\text { variables collected }\end{array}$ & $\begin{array}{l}\text { Criteria from other regions } \\
\text { used to estimate animal } \\
\text { distribution }\end{array}$ \\
\hline Fishing occurrence/ & $\begin{array}{l}\text { Surveyed fishing occurrence } \\
\text { per unit of distance or time } \\
\text { over seasons }\end{array}$ & $\begin{array}{l}\text { Spatial and/or temporal } \\
\text { distribution of fishing based } \\
\text { on interviews or expert } \\
\text { opinion }\end{array}$ & $\begin{array}{l}\text { Sparse or incomplete data, } \\
\text { no geospatial or precise } \\
\text { localization of fishing } \\
\text { effort/gear }\end{array}$ \\
\hline Bycatch/stranding data & $\begin{array}{l}\text { Data available from inter- } \\
\text { views or observers on boat or } \\
\text { stranding data; estimation of } \\
\text { bycatch rate possible }\end{array}$ & $\begin{array}{l}\text { Relative estimation of } \\
\text { bycatch from interviews or } \\
\text { stranding data }\end{array}$ & $\begin{array}{l}\text { No estimation of bycatch or } \\
\text { strandings available }\end{array}$ \\
\hline
\end{tabular}




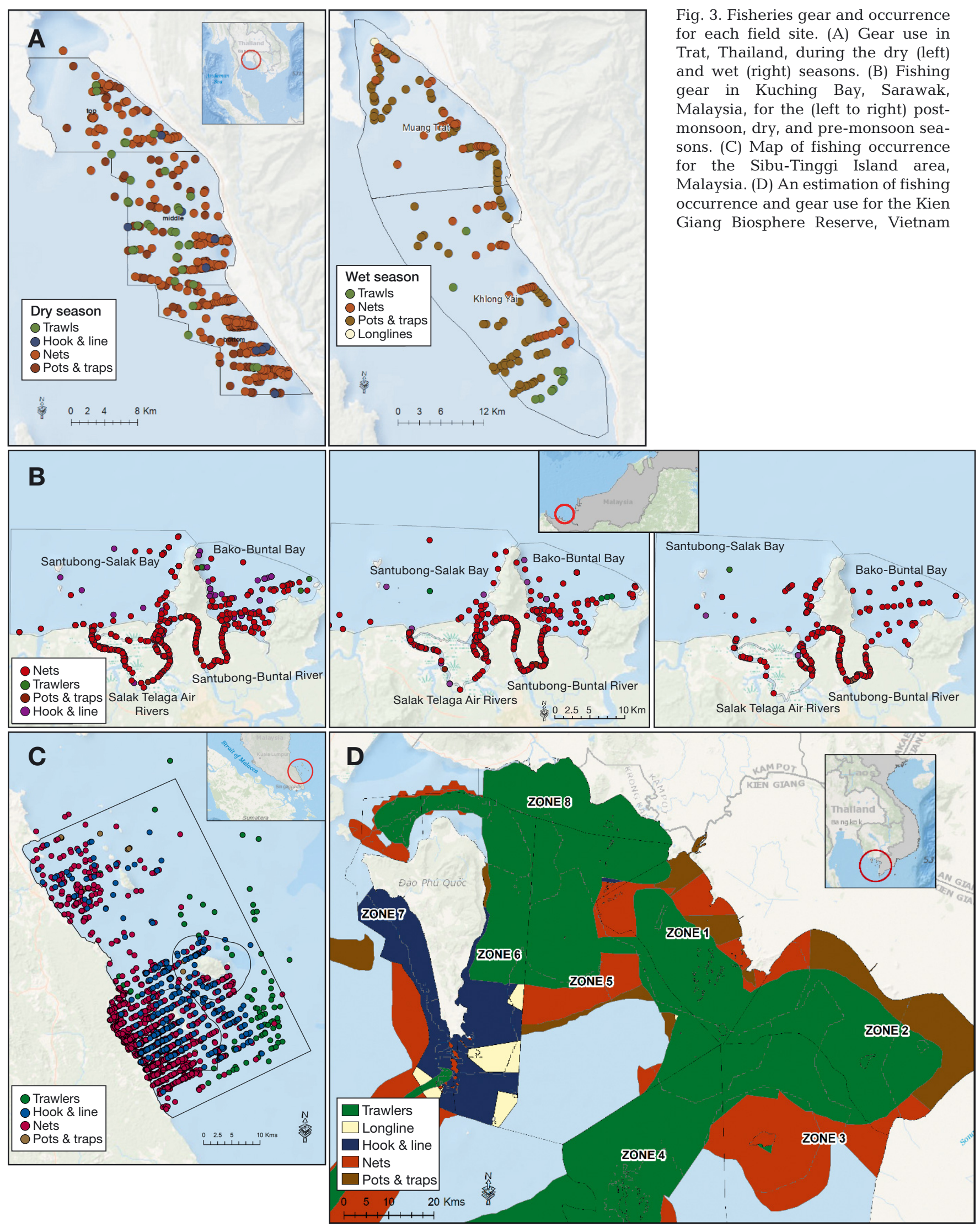


rence was most frequent throughout the rivers and in Bako-Buntal Bay in the post-monsoon and dry seasons. In the pre-monsoon season, there was less gillnetting in the bay, though activity was still high in the rivers.

In the Sibu-Tinggi Islands, based on sightings of boats during aerial surveys for dugongs, gillnets were seen predominantly close to the mainland shore, especially in the southern part of the region. Hook and line gear were further out towards the islands, and trawlers further offshore.

Estimated occurrence and gear distribution in the KGBR were based on the expert opinions of local scientists and Biosphere Reserve managers. We delineated polygons for each gear with their guidance. Gillnets and trawlers were most numerous, with longlines and hook and line gear used around the central and southern coasts of Phú Quốc Island.

\subsection{Habitat use}

We used Maxent to model habitat use for Trat, Kuching, and the Sibu-Tinggi Islands. The results of the different models tested and an explanation of models chosen can be found in the 'Habitat modeling' section of the Supplement. Here, we present the distribution of the low, medium, and high habitat suitability levels based on the contributed weights of the different environmental variables per site and per season.

\subsubsection{Trat Province, Thailand}

For both the dry and monsoon seasons, the variable that contributed most to dolphin habitat was distance to river mouth, with a percentage of $78.59 \%$ (SD =

Table 5. Summary of Maxent outputs for Trat, Thailand, with the average rate of the contributions of each variable from the 10 -fold cross-validation, and standard deviation in parentheses (see 'Habitat modeling' in the Supplement). The variables with the largest contributions for each season are in bold. AUC: area under the curve

\begin{tabular}{|lcc|}
\hline & Dry season & Monsoon season \\
\hline \multicolumn{2}{|l|}{ Environmental variable contributions (\%) } \\
Distance to river mouth & $\mathbf{7 8 . 5 9}(\mathbf{1 . 4 7 )}$ & $\mathbf{6 3 . 4 1}(\mathbf{2 . 4 2})$ \\
Distance to land & $8.74(2.36)$ & $4.64(1.40)$ \\
Depth & $12.47(1.51)$ & $31.93(2.43)$ \\
Slope & $0.19(0.29)$ & Not used in model \\
Maxent validation statistics & $85.05(0.04)$ & $85.85(0.03)$ \\
Mean test AUC & & \\
\hline
\end{tabular}

$1.47 \%$ ) and $63.21 \%(\mathrm{SD}=2.42 \%)$ for the dry and the monsoon seasons, respectively. However, the corresponding habitat differed between seasons (Table 5). Fig. 4A shows the results of the habitat modeling for Trat. During the dry season, the most suitable habitat extended along the coast between Ban Mai Rut and Khlong Yai. Around this highly suitable habitat, the likelihood of dolphin presence decreased with an increase of depth, the second most important environmental variable $(12.47 \%, \mathrm{SD}=1.51 \%)$. During the monsoon, the most suitable habitat shifted away from the coast and was divided into 2 main patches, one offshore of the northern part of the study area towards Trat Bay and one in the south from Khlong Yai towards the Cambodian border. The distance to river mouth continued to be the most influential parameter but with a smaller contribution, while the influence of depth became more important in comparison to the dry season (Table 5).

\subsubsection{Kuching Bay, Sarawak, Malaysia}

Fig. 4B shows the modeled probability of suitable habitat conditions for the Irrawaddy dolphin data in Kuching Bay organized by season. The ranges of the different levels of habitat suitability, as well as the contribution of the different environmental parameters to each model, differed between seasons. During the post-monsoon season, distance to land was the environmental parameter contributing the most to the model $(47.42 \%, \mathrm{SD}=2.00 \%)$, whereas for the dry and pre-monsoon seasons, the distance to the river mouth (dry season, $55.26 \%, \mathrm{SD}=2.18 \%$; pre-monsoon, $48.68 \%, \mathrm{SD}=2.94 \%$ ) was the most important parameter (Table 6). Suitable habitat, independent of the level of suitability (low, medium, or high), was further offshore in the pre-monsoon season and close to the land during the dry season. Highly suitable habitat centered in the rivers and just outside the river mouths during the dry season. During the postmonsoon, the highly suitable habitat extended further offshore along the coast into deeper waters.

\subsubsection{Sibu-Tinggi Islands, Malaysia}

In the Sibu-Tinggi Islands, the variables distance to river mouth and distance to land contributed to $76 \%$ of the model prediction (Table 7). The most suitable habitat for the dugongs was essentially close to the islands, where there are known seagrass meadows (Ooi et al. 2011, Ponnampalam et al. 2015) 

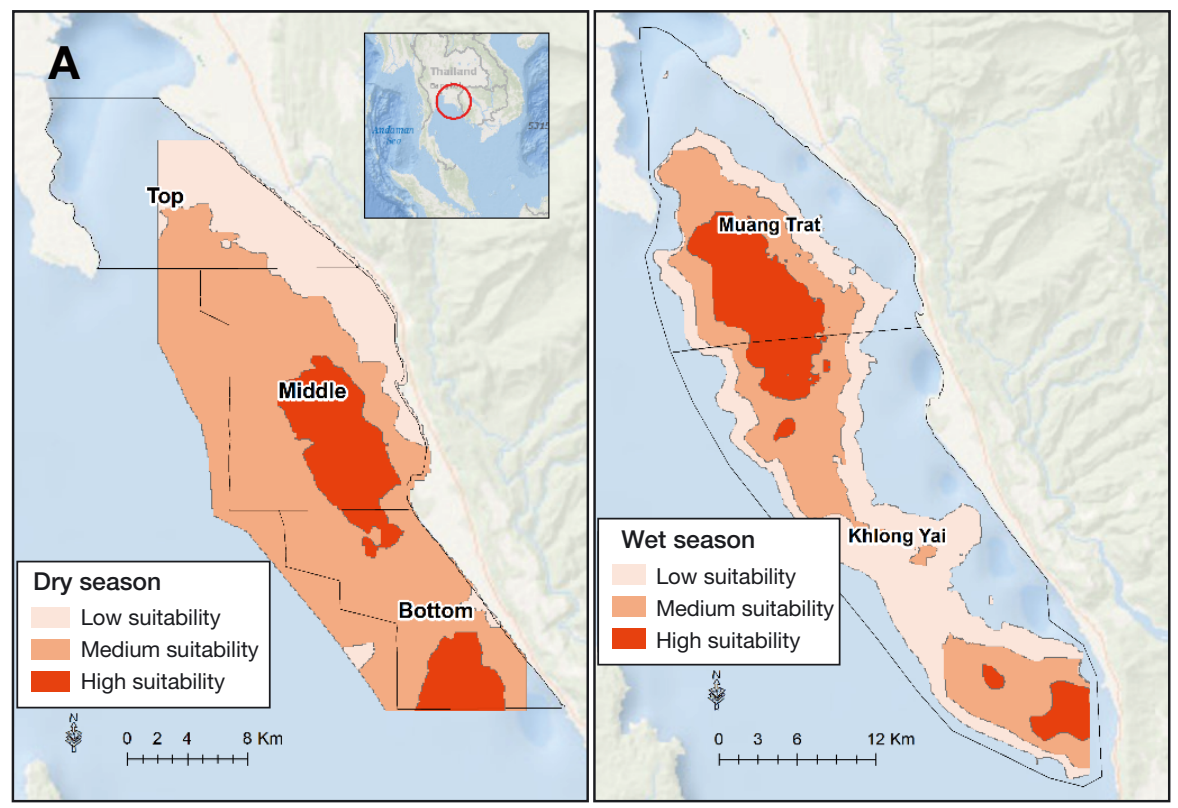

Fig. 4. Habitat suitability model results for each field site. (A) Irrawaddy dolphin habitat use in Trat, Thailand, during the dry (left) and wet (right) seasons. (B) Model results for Irrawaddy dolphins in Kuching Bay, Sarawak, Malaysia, for the (left to right) postmonsoon, dry, and pre-monsoon seasons. (C) Modeled habitat use for dugong in the Sibu-Tinggi Island area, Malaysia. (D) Suitable habitat for Irrawaddy dolphin in the Kien Giang Biosphere Reserve, Vietnam

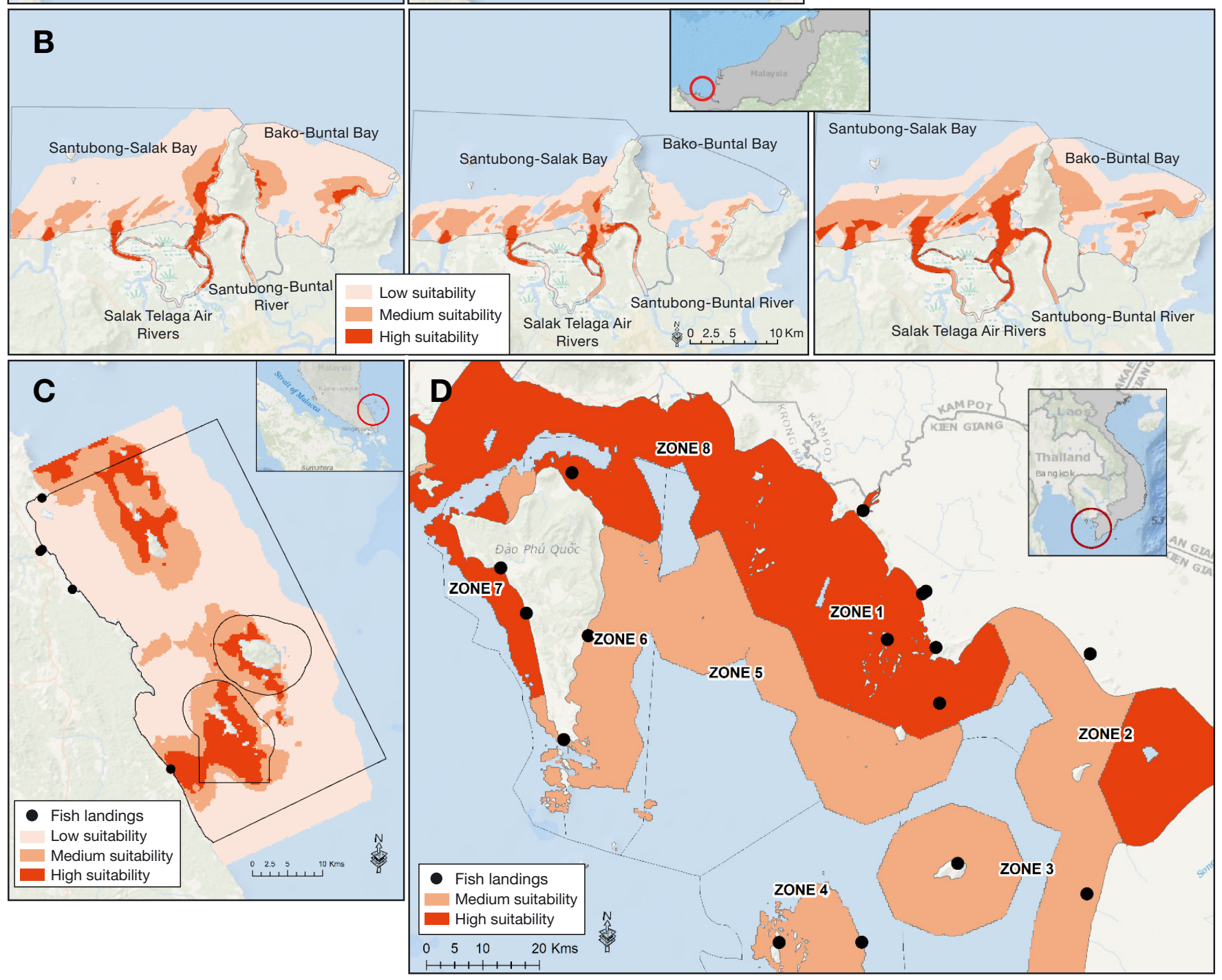


Table 6. Summary of Maxent outputs for Kuching Bay, Malaysia, with the average rate of the contributions of each variable from the 10-fold cross-validation, and standard deviation in parentheses (see 'Habitat modeling' in the Supplement). The variables with the largest contributions for each season are in bold. AUC: area under the curve

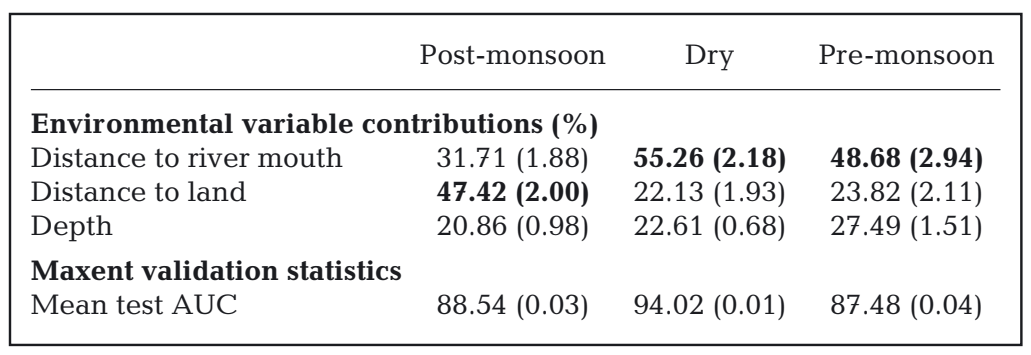

Table 7. Summary of Maxent outputs for the Sibu-Tinggi Islands, Malaysia, with the average rate of the contributions of each variable from the 10 -fold cross-validation, and standard deviation in parentheses (see 'Habitat modeling' in the Supplement). The variable with the largest contribution is in bold. AUC: area under the curve

\begin{tabular}{|lc|}
\hline Environmental variable contributions (\%) & \\
Distance to river mouth & $\mathbf{4 0 . 0 9}(\mathbf{0 . 9 6 )}$ \\
Distance to land & $34.96(0.95)$ \\
Depth & $24.78(0.86)$ \\
Slope & $0.16(0.03)$ \\
Maxent validation statistics & \\
Mean test AUC & $88.48(0.01)$ \\
\hline
\end{tabular}

(Fig. 4C). A large area of highly suitable habitat was predicted between Sibu Island and the mainland coast.

\subsubsection{Kien Giang Biosphere Reserve}

The most suitable habitat for Irrawaddy dolphins was along the coast, from the west of Phú Quốc Island in Zone 7 , through Zones 8 and 1 , and in Zone 2 into Rach Gia Bay. Medium ranked habitat was along the eastern coast of Phú Quốc, along Zone 1 and the coast of Zone 2. Medium ranked habitat was also around the islands of Son and Nam Du (Zones 3 and 4 respectively). As data were lacking and uncertainty was high in this area, we decided not to designate low quality habitat, so as not to assume dolphins were not using these areas (a possible false negative or Type II error).

\subsection{Bycatch risk}

Fig. 5 shows the spatial and seasonal risk of bycatch. In the dry season in Trat province (Fig. 5A), lower risk areas came right up to the coast. The areas of highest risk were concentrated offshore in the middle strata and off the coast of Khlong Yai, the major fishing port in the area, in the bottom strata. In contrast, risk was less concentrated in the wet season, further offshore, but medium and high risk areas were mapped in approximately the same areas.

For Kuching Bay (Fig. 5B), Irrawaddy dolphins and fishing activities shifted substantially across 3 seasons (postmonsoon, dry, and pre-monsoon) inside the riverine system and coastal areas. The highest bycatch risk to dolphins in Kuching Bay during the dry season was near the Salak Telaga Air and Santubong-Buntal Rivers. During the pre-monsoon season (September to December), predicted risk gravitated towards the estuary in southeast SantubongSalak Bay. Compared to the other seasons, bycatch risk in the post-monsoon season was more dispersed throughout the coastal marine areas and deeper inside the rivers. More than half (57\%) of the Santubong River system included areas where bycatch risk scores fell in the highest modeled suitable habitat range for Irrawaddy dolphins during the dry season.

In the Sibu-Tinggi Islands (Fig. 5C), dugongs using the marine areas in and around subregion 1 (Sultan Iskandar Marine Park surrounding Sibu Island) were at highest risk from gear used by vessels that likely originated from the mainland pier at Tanjung Leman. Intermediate to highest bycatch risk to dugongs covered almost two-thirds (62\%) of the entire subregion 1 area. Bycatch risk for dugongs was also high near Mersing, a local fishing port. High to medium risk was also concentrated around Besar Island to the north.

Bycatch risk in the KGBR (Fig. 5D) was highest on the eastern side of Phú Quốc Island (subregion 6), around the islands of Son Hai in the Ba Lua archipelago (subregion 1), and west of Hà Tiên city (subregion 5).

\subsection{Uncertainty}

Based on the standards shown in Table 4, we determined the level of uncertainty for each data category for each site (Table 8). Fig. 5 also shows the stoplight levels of uncertainty for the bycatch risk maps for each area. All except KGBR show a combination of yellow and green. KGBR, based on criteria in Tables 4 and 5, has a combination of yellow and red. 


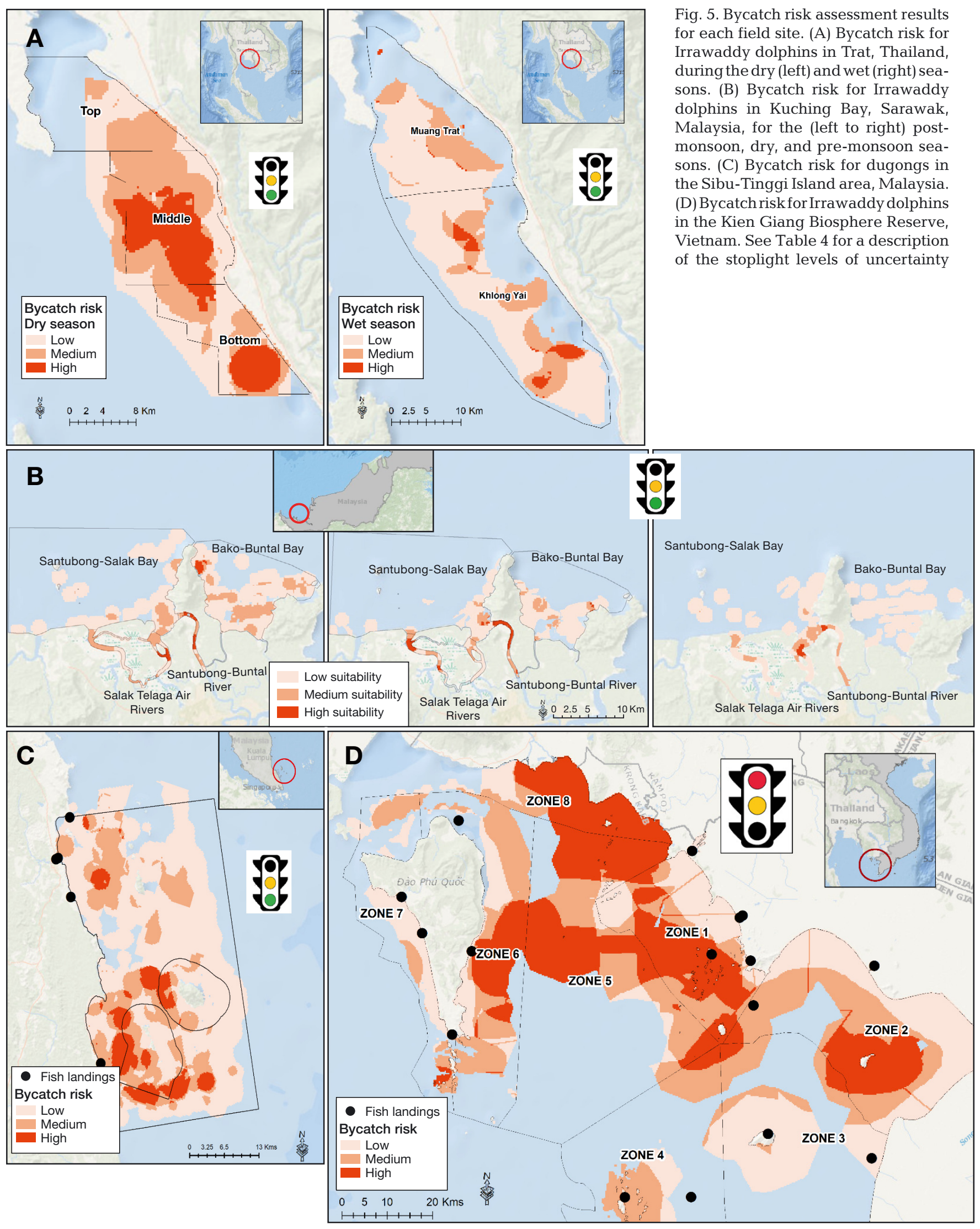


Table 8. Characterizations of uncertainty for bycatch toolbox criteria at each field site. See color scheme in Table 4

\begin{tabular}{|c|c|c|c|c|}
\hline & Trat & Kuching & Sibu-Tinggi & Kien Giang \\
\hline $\begin{array}{l}\text { Animal sightings/dis- } \\
\text { tribution }\end{array}$ & $\begin{array}{l}\text { Systematic line transect } \\
\text { boat and photo-ID } \\
\text { survey }\end{array}$ & $\begin{array}{c}\text { Systematic line transect } \\
\text { boat and photo-ID } \\
\text { survey }\end{array}$ & $\begin{array}{l}\text { Systematic line } \\
\text { transect aerial survey }\end{array}$ & $\begin{array}{l}\text { Systematic line transect } \\
\text { boat and photo-ID } \\
\text { survey but not } \\
\text { enough sightings to } \\
\text { characterize } \\
\text { abundance/distribution }\end{array}$ \\
\hline Habitat suitability & $\begin{array}{l}\text { Environmental data } \\
\text { collected with line } \\
\text { transect survey }\end{array}$ & $\begin{array}{l}\text { Environmental data } \\
\text { collected with line } \\
\text { transect survey }\end{array}$ & $\begin{array}{c}\text { Seagrass data and } \\
\text { mammal acoustics; } \\
\text { limited environmental } \\
\text { data collected during } \\
\text { survey }\end{array}$ & $\begin{array}{c}\text { Environmental data } \\
\text { partially collected }\end{array}$ \\
\hline $\begin{array}{c}\text { Fishing } \\
\text { occurrence/gear type } \\
\text { and seasonality }\end{array}$ & $\begin{array}{l}\text { Collected during line } \\
\text { transect survey and } \\
\text { data from interviews }\end{array}$ & $\begin{array}{l}\text { Collected during line } \\
\text { transect survey and } \\
\text { data from interviews }\end{array}$ & Data from interviews & $\begin{array}{l}\text { From expert knowledge } \\
\text { and some interviews }\end{array}$ \\
\hline $\begin{array}{l}\text { Bycatch/stranding } \\
\text { data }\end{array}$ & $\begin{array}{l}\text { Bycatch determination } \\
\text { coming from necropsies } \\
\text { of stranded animals; } \\
\text { regional stranding } \\
\text { network }\end{array}$ & $\begin{array}{l}\text { Presence/absence } \\
\text { of bycatch from } \\
\text { interviews }\end{array}$ & $\begin{array}{l}\text { From interviews and } \\
\text { some records of } \\
\text { animals which had } \\
\text { stranded due to } \\
\text { fisheries interactions }\end{array}$ & $\begin{array}{l}\text { Presence/absence } \\
\text { of bycatch from } \\
\text { interviews }\end{array}$ \\
\hline
\end{tabular}

Where formal surveys had been conducted, at Thai and Malaysian sites, uncertainty was lowest, or green. KGBR, with few formal surveys or sightings, was rated the highest for uncertainty, or red. The highest amount of environmental data for habitat modeling was available for Trat. Both Malaysian sites had some data collected, with more formal data in Kuching. These sites were designated a combination of green and yellow. In KGBR, only minimal environmental data were collected. Both Trat and Kuching Bay collected fisheries data during formal abundance surveys. In Sibu-Tinggi, there were some data on fisheries occurrence from interviews, sufficientbased on our standards - to be labeled green and yellow. There was some knowledge of fishing boat locations and gear in KGBR from interviews with local agency scientists. For all sites, data on bycaught animals were available from interviews. In Thailand, there was a stranding network and there were agency scientists performing necropsies to determine cause of death. However, for no field site was an estimation of bycatch rate possible, so all sites were marked yellow.

\subsection{Exposure/consequence plots and gear}

For Trat province during the dry season, the 3 regions had similar levels of exposure and consequence, with the middle region showing more risk
(Fig. 6). Nets, including gillnets, purse seine, and surrounding nets (Table 3 ), had the highest percentage of risk for bycatch in all regions, followed by pots and traps (crab traps and octopus traps) (Table S2). In the monsoon season, there was a clearly higher risk of consequence in the lower Khlong Yai region. Nets were the riskiest gear in the Muang Trat region, but were not present in Khlong Yai. Pots and traps were the highest risk gear in this lower area.

In Kuching Bay, the exposure/consequence scores of all 4 sites were spread along a range of exposure at a high level of consequence (Fig. 6). In all 3 seasons, the Santubong-Buntal River showed the highest level of exposure and Salak-Santubong Bay the lowest. In the dry season, Bako Buntal Bay was the highest in consequence. In the Santubong-Buntal River, nets showed the highest percentage of risk for bycatch in all seasons, followed by pots and traps (Table S2 in the Supplement). Nets in Kuching Bay included gillnets (hung from buoys at the surface), set nets (staked to the seabed), drift nets (drifting on currents), and trammel nets ( 2 to 3 layers of variable mesh size netting) (Table 3). In Salak-Santubong Bay, the same was true during the post-monsoon and dry seasons. During the pre-monsoon, nets were followed in risk by hook and line gear. In the Salak Telaga Air River, nets and pots and traps were the riskiest; however, in the pre-monsoon season, fishers only used nets and hook and line gear. In Bako Buntal Bay, there were no pots and traps. Nets had the highest risk of bycatch, 


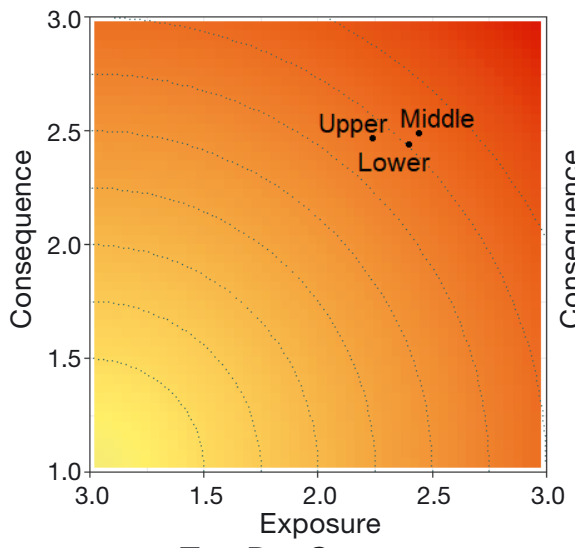

Trat Dry Season
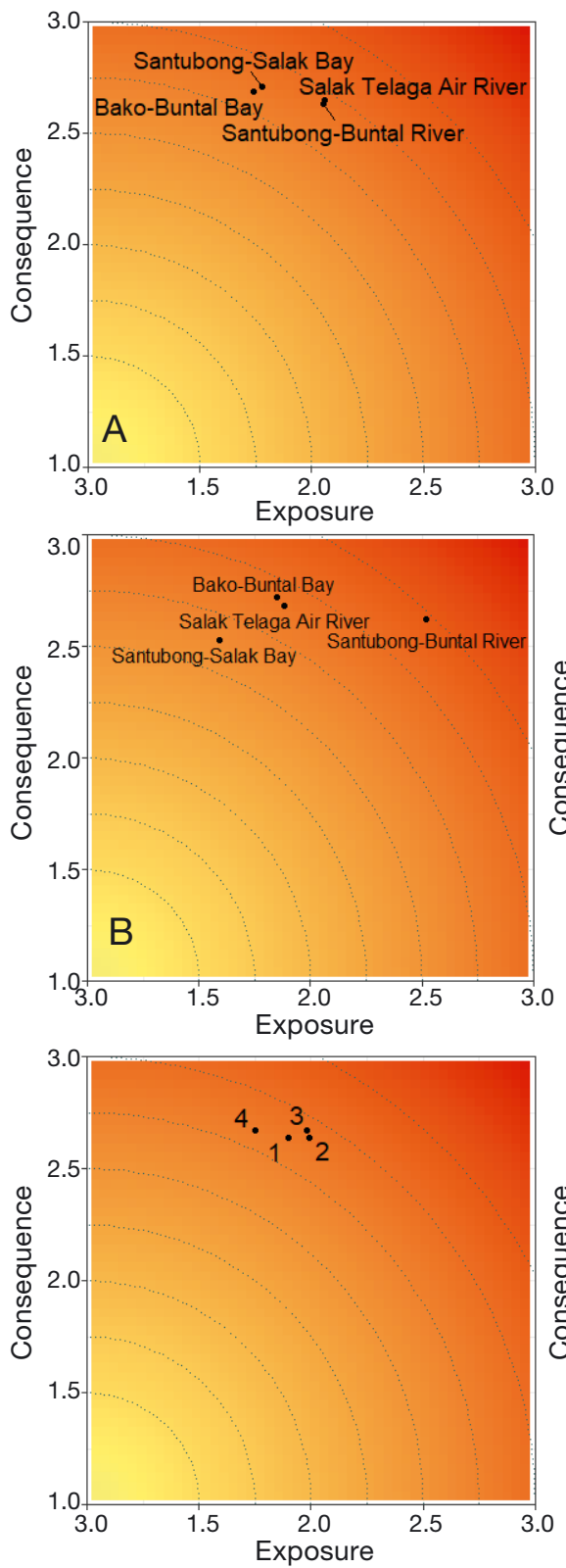

Sibu-Tinggi Islands

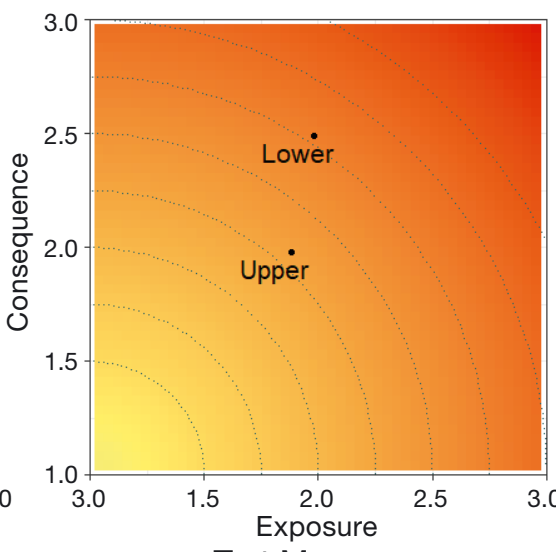

Trat Monsoon
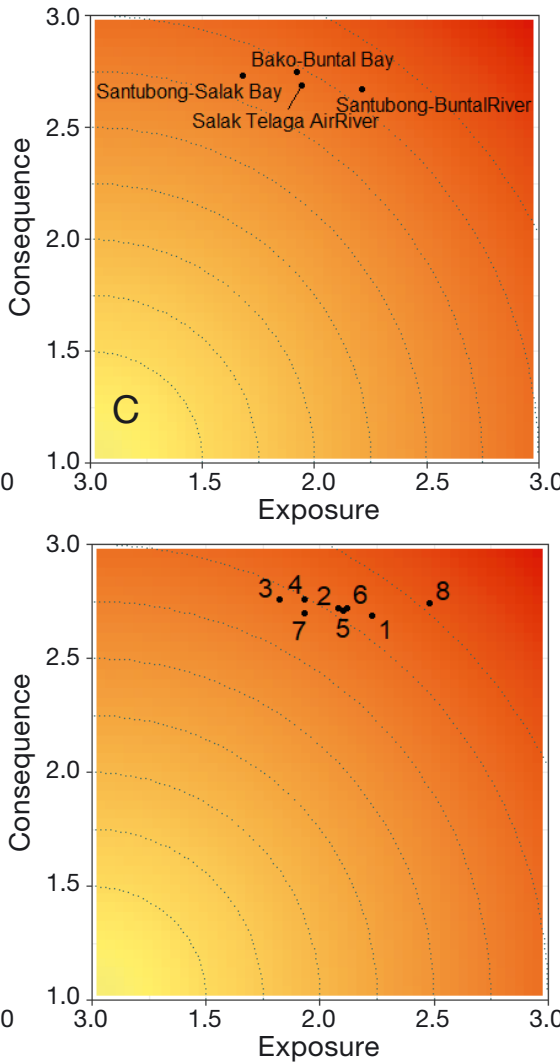

Kien Giang Biosphere Reserve followed by trawlers, except in the pre-monsoon season, when nets were the only gear present.

The exposure/consequence plots for the Sibu-Tinggi Islands showed similar ratings with medium exposure and high consequence (Fig. 6). For all 4 zones, nets (gillnets and drift nets; Table 3) were the riskiest gear, with trawlers second (Table S2). In the KGBR, all regions indicated high consequence and a range of medium exposure, with region 3 around Són Island at the lowest level of exposure, and region 8 in the northeast of the Reserve along the Cambodian border at the highest (Fig. 6). In all 8 zones, nets were at the highest risk for bycatch (see Table 3 for a list), with trawlers second. In KGBR, the trawler category included not only single trawlers, but also paired and electric trawlers.

\section{DISCUSSION}

The first test of the ByRA toolkit, built on a diverse set of case studies, put existing data from 3 SE Asian countries into a cohesive risk assessment and scenario framework that can support marine mammal bycatch management planning. The ByRA results provided resident scientists and managers with information on areas and seasons of bycatch risk, as well as the levels of risk for various fishing gear at those times and locations, which could then support pre-

Fig. 6. Exposure/consequence diagrams for each field site. Panels labelled A-C represent (A) post-monsoon, (B) dry, and (C) premonsoon in Kuching Bay. Regions with marine mammals in a space with high exposure to fishing activities and at a population level that experiences a greater consequence to bycatch are at the highest risk levels on a scale from 1 to 3. See Fig. 2 for subregions corresponding to numbers in the Sibu-Tinggi Islands and the Kien Giang Biosphere Reserve 
cautionary actions and policies, and inform carefully designed research.

Irrawaddy dolphins are listed as Endangered on the IUCN Redlist (Minton et al. 2017), and dugongs are listed as Vulnerable (Marsh \& Sobtzick 2015), with fisheries bycatch recognized as the most significant human-induced threat for both species (Reeves et al. 2013, Brownell et al. 2019). As such, we should use whatever data are available now to inform management and conservation interventions that can be implemented as soon as possible, rather than waiting for more data to be collected. Waiting can result in continued population declines, as evidenced by the vaquita and others (e.g. Turvey et al. 2007, JaramilloLegorreta et al. 2019). As research efforts progress at our sites, more substantiated scenarios can be run and the uncertainty in toolbox results will decrease. For each field site, the application of ByRA was different, and outputs led to different actual and proposed management and research strategies.

In Thailand, the Department of Marine and Coastal Resources presented the ByRA results to village stakeholders to illustrate bycatch risk activities in local areas. The mapped results were used in a marine protected area planning process (still ongoing) to establish marine conservation zones in Trat Bay. The Irrawaddy dolphin is considered a critical flagship species in MPA planning. Bycatch risk maps showed the different patterns of fishing and gear use, as well as how habitat use changes for the Irrawaddy dolphins between the wet and dry seasons. Smaller areas of risk in the wet season reflected less use of fishing gear and fewer animals sighted (Junchompoo et al. 2013). The ByRA results are being used to plan fishing gear use restrictions and seasonal closures based on how bycatch risk can change throughout the year. Input on conservation zoning is being determined based on public hearings. The challenge of implementing this planning process is how to balance local livelihoods with conservation-oriented management.

In Kuching Bay, the ByRA results, changing by season, especially in the rivers, aligned with what has been observed in the field. Results showing high risk areas will be used to engage local fishing communities and ask for their input on how to reduce the risk of entanglement at various times of the year, for example by ensuring that nets are not left unattended. When combined with interview results, the mapped results show that fishers from certain villages may be more likely to be involved with entanglement incidents than others. Interventions, such as awareness raising workshops and disentanglement training, can be focused on these villages. ByRA results will be used to design robust trials for mitigation measures in higher risk area - e.g. the effectiveness of attending nets versus leaving them unattended, trials of acoustic deterrent devices on nets, and time/area closures. The risk maps will be used to engage local government agencies and Sarawak Forestry, and work on a collaborative strategy with them to trial, and eventually introduce and enforce effective mitigation measures.

In the Sibu-Tinggi Island area, risk patterns were seen to be driven by multiple factors including the intensive use of gillnets, a gear known to entangle dugongs (reflected in ByRA's likelihood of capture criterion), which are frequently observed in extensive seagrass beds and shallow depths (highly suitable habitat). The ByRA output will be shared with the Department of Fisheries Malaysia and the Department of Marine Park Malaysia to assist them with better management planning and enforcement. These outputs will also be used as a basis for recommending that the agencies use the M2 Marine Monitor System to monitor vessel activities in real time, so that illegal activities (such as ghost or unattended longlines) may be intercepted. The M2 is a low-cost radar system that detects and tracks vessel activity in nearshore protected areas to support monitoring and enforcement efforts (www.protectedseas.net). The Marecet research group has been using the ByRA output as guidance for further research planning, particularly which aspects of data collection they need to improve. They are continuing to collect better environmental data, and create more efficient methods for monitoring bycatch and strandings.

For the KGBR, the management board of the reserve will use the risk maps to assist the local Fishery Department and the People's Committee of Kien Giang Province in the management of the fishing zones to reduce bycatch. Although there was a high level of uncertainty regarding the area of highbycatch risk in KGBR, the risk map allows the management board to raise concerns about bycatch in KGBR to the higher level national authorities. Additionally, the scientists of the Vietnam Marine Megafauna Network will utilize the results from the ByRA toolkit to plan future research and monitoring efforts in the highest risk areas. They will work to reduce uncertainty and fill in data gaps, including methods such as acoustics, formal line transects, and photoidentification surveys to obtain more information on marine mammal distribution, as well as badly needed data on fisheries occurrence and gear use. The joint efforts of the Vietnam Marine Megafauna Network 
and the management board of the KGBR will ensure the results of ByRA toolbox are translated into better management and conservation planning.

By synthesizing and organizing bycatch risk assessment methods in an accessible framework, the reach of our project extends beyond the local areas used to demonstrate the toolkit. For further information about the Southeast Asian project described in this paper, see http://cons.scienceontheweb.net/bycatch/.

At the time of this writing, workshops on how to use the ByRA toolbox have been conducted by the development team in Malaysia, Thailand, India, and Vietnam. Workshops in other regions are scheduled for the coming year. Our goal is for an open-source toolbox to be available to download and use along with a manual, now translated into Spanish.

This research represents the first regional view of how these methods can support practitioners to estimate marine mammal distribution, fisheries gear use, and bycatch, and find effective measures to reduce bycatch to sustainable levels. Syntheses of ByRA outputs can suggest management interventions by subregion, species, and gear type for targeting at-risk areas and reducing risk. Spatially and temporally explicit scenarios can be built and further improved to evaluate conservation outcomes for additional taxa with large-scale and transient habitat requirements.

Acknowledgements. Agencies and non-profit organizations for the sites included the Department of Marine and Coastal Resources (DMCR) in Thailand, the Kien Giang Biosphere Reserve Management Board (KGBRMB), Department of Marine Park Malaysia, the Institute of Biodiversity and Environmental Conservation at University Malaysia Sarawak, MareCet Malaysia, and Sarawak Forestry. We especially appreciated working with Marine Conservation Cambodia for contributing data about Irrawaddy dolphins and fishing effort along the northwestern boundary of Kien Giang Biosphere Reserve. Thank you to the Bycatch Mitigation Initiative of the International Whaling Commission for funding the Spanish translation of our manual. We would like to thank Nina Young for her support and inspiration, and Max Czapanskiy for R advice. Funding for this project was from the U.S. National Office of Atmospheric Administration Office of International Affairs and Seafood Inspection Award Number: NA16NMF4630338.

\section{LITERATURE CITED}

Annual Fisheries Statistics Malaysia (2018) https://www.iotc. org/sites/default/files/documents/2017/10/IOTC-2017WPDCS13-18_-_MYS.pdf (accessed 02 December 2019)

Arkema KK, Verutes GM, Bernhardt JR, Clarke C and others (2014) Assessing habitat risk from human activities to inform coastal and marine spatial planning: a demonstration in Belize. Environ Res Lett. 9(11):114016
Briscoe DK, Hiatt S, Lewison R, Hines E (2014) Modeling habitat and bycatch risk for dugongs in Sabah, Malaysia. Endang Species Res 24:237-247

Brownell RL Jr, Reeves RR, Read AJ, Smith BD and others (2019) Bycatch in gillnet fisheries threatens Critically Endangered small cetaceans and other aquatic megafauna. Endang Species Res 40:285-296

Department of Fisheries Malaysia (2018) https://www.dof.gov. my/index.php/pages/view/3754 (accessed 24 Feb 2020)

* Dunn DC, Stewart K, Bjorkland RH, Haughton $M$ and others (2010) A regional analysis of coastal and domestic fishing effort in the wider Caribbean. Fish Res 102:60-68

* Elith J, Phillips SJ, Hastie T, Dudík M, Chee YE, Yates CJ (2011) A statistical explanation of MaxEnt for ecologists. Divers Distrib 17:43-57

Federal Register (2016) Fish and fish product import provisions of the Marine Mammal Protection Act. https://www. federalregister.gov/documents/2016/08/15/2016-19158/ fish-and-fish-product-import-provisions-of-the-marinemammal-protection-act (accessed 4 Dec 2019)

KGibbs MT, Browman HI (2015) Risk assessment and risk management: a primer for marine scientists. ICES J Mar Sci 72:992-996

Goldsworthy SD, Page B (2007) A risk-assessment approach to evaluating the significance of seal bycatch in two Australian fisheries. Biol Conserv 139:269-285

Grech A, Marsh H, Coles R (2008) A spatial assessment of the risk to a mobile marine mammal from bycatch. Aquat Conserv 18:1127-1139

*Gregr EJ, Baumgartner MF, Laidre KL, Palacios DM (2013) Marine mammal habitat models come of age: the emergence of ecological and management relevance. Endang Species Res 22:205-212

*Hines E, Adulyanukosol K, Duffus D, Dearden P (2005) Community perspectives and conservation needs for dugongs (Dugong dugon) along the Andaman coast of Thailand. Environ Manage 36:654-664

Hines E, Reynolds J, Mignucci-Giannoni A, Aragones LV, Marmontel M (eds) (2012) Sirenian conservation: issues and strategies in developing countries. The University Press of Florida, Gainesville, FL

Hines E, Ponnampalam LS, Hisne FIJ, Whitty TS, JacksonRicketts J, Kuit SH, Acebes JM (2015a) Report of the 3rd Southeast Asian Marine Mammal Symposium (SEAMAM III). Langkawi Island, Malaysia, 4-10 March 2013. Convention on Migratory Species of Wild Animals (CMS), United Nations Environment Program. www.cms.int/en/ publication/report-third-southeast-asian-marine-mam mals-symposium-seamam-iii (accessed 2 Dec 2019)

Hines E, Strindberg S, Jumchumpoo C, Ponnampalam L, Ilangakoon A, Jackson-Ricketts J (2015b) Line transect estimates of Irrawaddy dolphin abundance along the eastern Gulf of Thailand. Front Mar Sci 2:63

* Hobday AJ, Smith ADM, Stobutzki IC, and others (2011) Ecological risk assessment for the effects of fishing. Fish Res 108:372-384

* Hoffman FO, Hammonds JS (1994) Propagation of uncertainty in risk assessments: the need to distinguish between uncertainty due to lack of knowledge and uncertainty due to variability. Risk Anal 14:707-712

Jackson-Ricketts J (2016) Diet, life history, habitat, and conservation of Irrawaddy dolphins (Orcaella brevirostris) in the Gulf of Thailand. PhD dissertation, University of California, Santa Cruz, CA 
Jackson-Ricketts J, Junchompoo C, Hines EM, Hazen EL, Ponnampalam LS, Ilangakoon A, Monanunsap S (2020) Habitat modeling of Irrawaddy dolphins (Orcaella brevirostris) in the eastern Gulf of Thailand. Ecol Evol 10: 2778-2792

Jaramillo-Legorreta AM, Cardenas-Hinojosa G, Nieto-Garcia E, Rojas-Bracho L and others (2019) Decline towards extinction of Mexico's vaquita porpoise (Phocoena sinus). R Soc Open Sci 6:190598

Johnson AF, Caillat M, Verutes GM, Peter C and others (2017) Poor fisheries struggle with U.S. import rule. Science 355:1031-1032

Junchompoo C, Monanunsap S, Penpein C (2013) Population and conservation status of Irrawaddy dolphins (Orcaella brevirostris) in Trat Bay, Trat province, Thailand. Proceedings of the Design Symposium on Conservation of Ecosystems. The 13th SEASTAR2000 workshop. Kyoto University, Japan

Lewison RL, Crowder LB, Read A, Freeman S (2004) Understanding impacts of fisheries bycatch on marine megafauna. Trends Ecol Evol 19:598-604

* Lewison RL, Soykan C, Franklin J (2009) Mapping the bycatch seascape: multispecies and multi-scale spatial patterns of fisheries bycatch. Ecol Appl 19:920-930

Marsh H, Sobtzick S (2015) Dugong dugon. The IUCN Red List of Threatened Species 2015: e.T6909A43792211. http://dx.doi.org/10.2305/IUCN.UK.2015-4.RLTS.T6909 A43792211.en. (accessed 4 Dec 2019)

Maxwell SM, Hazen EL, Bograd SJ, Halpern BS and others (2013) Cumulative human impacts on marine predators. Nat Commun 4:2688

Minton G, Peter C, Tuen AA (2011) Distribution of small cetaceans in the nearshore waters of Sarawak. Raffles Bull Zool 59:91-100

Minton G, Peter C, Zulkifli Poh AN, Ngeian J, Braulik G, Hammond PS, Tuen AA (2013) Population estimates and distribution patterns of Irrawaddy dolphins (Orcaella brevirostris) and Indo-Pacific finless porpoise (Neophocaena phocaenoides) in the Kuching Bay, Sarawak. Raffles Bull Zool 61:877-888

Minton G, Smith BD, Braulik GT, Kreb D, Sutaria D, Reeves RR (2017) Orcaella brevirostris (errata version published in 2018). The IUCN Red List of Threatened Species 2017: e.T15419A123790805. http://dx.doi.org/10.2305/IUCN. UK.2017-3.RLTS.T15419A50367860.en. (accessed 4 Dec 2019)

Muscarella R, Galante PJ, Soley-Guardia M, and others (2014) ENMeval: an R package for conducting cpatially independent evaluations and estimating optimal model complexity for Maxent ecological niche models. Methods Ecol Evol 5:1198-1205

Official Journal of the European Union (2019) Regulation (EU) 2019/1241 of the European Parliament and of the Council of 20 June 2019. https://eur-lex.europa.eu/legalcontent/EN/TXT/PDF/?uri=CELEX:32019R1241\&from= EN

Ooi JLS, Kendrick GA, Van Niel KP, Affendi YA (2011) Knowledge gaps in tropical Southeast Asian seagrass systems. Estuar Coast Shelf Sci 92:118-131

Ortega-Argueta A, Hines EM, Calvimontes J (2012) Using interviews in sirenian research. In: Hines E, Reynolds J, Mignucci-Giannoni A, Aragones LV, Marmontel M (eds) Sirenian conservation: issues and strategies in developing countries. The University Press of Florida, Gainesville, FL, p 109-115
Pearson RG, Raxworthy CJ, Nakamura M, Townsend Peterson A (2007) Predicting species distributions from small numbers of occurrence records: a test case using cryptic geckos in Madagascar. J Biogeogr 34:102-117

* Peter C, Zulkifli Poh AN, Ngeian J, Tuen AA, Minton G (2016) Identifying habitat characteristics and critical areas of Irrawaddy dolphin habitat (Orcaella brevirostris) in Kuching Bay, Sarawak, Malaysia: implications for conservation. In: Das I, Tuen AA (eds) Naturalists, explorers and field scientists in Southeast Asia and Australasia, Vol 15, Topics in biodiversity and conservation. Springer, Cham

Philip GM, Watson DF (1982) A precise method for determining contoured surfaces. Australian Petroleum Explor Assoc J 22:205-212

* Phillips SJ, Anderson RP, Schapire RE (2006) Maximum entropy modeling of species geographic distributions. Ecol Modell 190:231-259

* Pilcher NJ, Adulyanukosol K, Das H, Davis P and others (2017) A low-cost solution for documenting distribution and abundance of endangered marine fauna and impacts from fisheries. PLOS ONE 12:e0190021

* Ponnampalam LS, Izmal JHF, Adulyanukosol K, Ooi JLS, Reynolds JE (2015) Aligning conservation and research priorities for proactive species and habitat management: the case of dugongs Dugong dugon in Johor, Malaysia. Oryx 49:743-749

Read AJ, Drinker P, Northridge S (2006) Bycatch of marine mammals in U.S. and global fisheries. Conserv Biol 20: 163-169

Redfern JV, Ferguson MC, Becker EA, Hyrenbach KD and others (2006) Techniques for cetacean-habitat modeling. Mar Ecol Prog Ser 310:271-295

Reeves RR, Smith BD, Crespo EA, Notobartolo di Sciara G (compilers) (2003) Dolphins, whales and porpoises: 2002-2010. Conservation action plan for the world's cetaceans. IUCN/SSC Cetacean Specialist Group. IUCN, Gland

* Reeves RR, McClellan K, Werner TB (2013) Marine mammal bycatch in gillnet and other entangling net fisheries, 1990 to 2011. Endang Species Res 20:71-97

Rhoden CM, Peterman WE, Taylor CA (2017) Maxentdirected field surveys identify new populations of narrowly endemic habitat specialists. PeerJ 5:e3632

* Roberts CM, McClean CJ, Veron JEN, and others (2002) Marine biodiversity hotspots and conservation priorities for tropical reefs. Science 295:1280-1284

Samhouri JF, Levin PS (2012) Linking land- and sea-based activities to risk in coastal ecosystems. Biol Conserv 145: 118-129

Sharp R, Tallis HT, Ricketts T, Guerry AD and others (2018) InVEST 3.6.0 User's Guide. The Natural Capital Project, Stanford University, University of Minnesota, The Nature Conservancy, and World Wildlife Fund. http://data.natural capitalproject.org/nightly-build/invest-users-guide/html/ habitat_risk_assessment.html (accessed 2 Dec 2019)

Soykan CU, Moore JE, Žydelis R, Crowder LB, Safina C, Lewison RL (2008) Why study bycatch? An introduction to the Theme Section on fisheries bycatch. Endang Species Res 5:91-102

Stelzenmüller V, Fock HO, Gimpel A, Rambo H and others (2015) Quantitative environmental risk assessments in the context of marine spatial management: current approaches and some perspectives. ICES J Mar Sci 72: 1022-1042 
Stewart KR, Lewison RL, Dunn DC, Bjorkland RH, Kelez S, Halpin PN, Crowder LB (2010) Characterizing fishing effort and spatial extent of coastal fisheries. PLOS ONE 5:e14451

Teck SJ, Halpern BS, Kappel CV, and others (2010) Using expert judgement to estimate marine ecosystem vulnerability in the California current. Ecol Appl 20:1402-1416

Teh SLL, Teh CLL, Hines E, Junchumpoo C, Lewison RL (2015) Contextualizing the coupled socio-ecological conditions of marine megafauna bycatch. Ocean Coast Manage 116:449-465

Editorial responsibility: Jeremy Kiszka, North Miami, Florida, USA
Turvey ST, Pitman RL, Taylor BL, Barlow J, Akamatsu T and others (2007) First human-caused extinction of a cetacean species? Biol Lett 3:537-540

Vu L (2014) Conservation status of cetaceans in Kien Giang biosphere reserve, Kien Giang province, Vietnam. Final report to Rufford Small Grant foundation. RSG reference 10664-1. Rufford Foundation, London

* Williams R, Burgess MG, Ashe E, Gaines SD, Reeves RR (2016) US seafood import restriction presents opportunity and risk. Science 354:1372-1374

Submitted: December 22, 2019; Accepted: April 3, 2020

Proofs received from author(s): May 19, 2020 